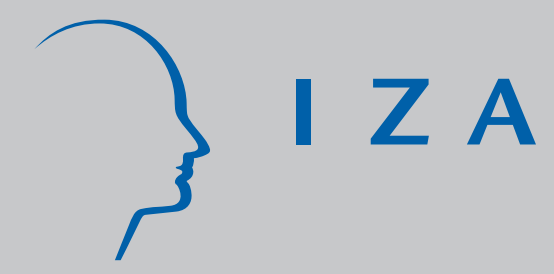

IZA DP No. 555

How Much Language is Enough? Some Immigrant Language Lessons from Canada and Germany

Don J. DeVoretz

Holger Hinte

Christiane Werner

August 2002 


\title{
How Much Language is Enough? Some Immigrant Language Lessons from Canada and Germany
}

\author{
Don J. DeVoretz \\ Simon Fraser University, RIIM and IZA Bonn \\ Holger Hinte \\ IZA Bonn \\ Christiane Werner \\ Simon Fraser University, RIIM (until 2001) \\ Associated Economic Consultants, Vancouver (since 2001)
}

\author{
Discussion Paper No. 555 \\ August 2002
}

\author{
IZA \\ P.O. Box 7240 \\ D-53072 Bonn \\ Germany \\ Tel.: +49-228-3894-0 \\ Fax: +49-228-3894-210 \\ Email: iza@iza.org
}

This Discussion Paper is issued within the framework of IZA's research area Mobility and Flexibility of Labor. Any opinions expressed here are those of the author(s) and not those of the institute. Research disseminated by IZA may include views on policy, but the institute itself takes no institutional policy positions.

The Institute for the Study of Labor (IZA) in Bonn is a local and virtual international research center and a place of communication between science, politics and business. IZA is an independent, nonprofit limited liability company (Gesellschaft mit beschränkter Haftung) supported by the Deutsche Post AG. The center is associated with the University of Bonn and offers a stimulating research environment through its research networks, research support, and visitors and doctoral programs. IZA engages in (i) original and internationally competitive research in all fields of labor economics, (ii) development of policy concepts, and (iii) dissemination of research results and concepts to the interested public. The current research program deals with (1) mobility and flexibility of labor, (2) internationalization of labor markets, (3) welfare state and labor market, (4) labor markets in transition countries, (5) the future of labor, (6) evaluation of labor market policies and projects and (7) general labor economics.

IZA Discussion Papers often represent preliminary work and are circulated to encourage discussion. Citation of such a paper should account for its provisional character. A revised version may be available on the IZA website (www.iza.org) or directly from the author. 
IZA Discussion Paper No. 555

August 2002

This paper is also available in German language at ftp://ftp.iza.org/dps/dp555d.pdf

\section{ABSTRACT}

\section{How Much Language is Enough? \\ Some Immigrant Language Lessons from Canada and Germany*}

Germany and Canada stand at polar ends of the scientific debate over language integration and ascension to citizenship. German naturalization, as of January 2000, contains an explicit language criterion for naturalization. The first German immigration act that will presumably come into effect on January 1, 2003, does not only concentrate on control aspects but also aims at language as a criterion for legal immigration. Canada, in effect, does not base entry or citizenship on knowledge of either of its official languages. Acquisition of a second language in Canada is voluntary and largely dependent on labour market incentives. Which system of second language acquisition - the statist German system or the laissez faire Canadian model - provides the best milieu for immigrant second language acquisition? This paper undertakes a comparative review of Canadian and German legal and educational programs in order to answer this question.

JEL Classification: F22, I29, J60, J61

Keywords: immigration, integration, language skills, migration politics, citizenship

Don J. DeVoretz

RIIM

Simon Fraser University

Burnaby, BC, V5A 1 S6

Canada

Tel.: +1 (604)-291-4575

Fax: +1 (604)-291-5336

Email: devoretz@sfu.ca

\footnotetext{
*This study was a joint effort of IZA (Bonn) Germany and RIIM (Vancouver) Canada. The critical comments of D. Coulombe and C. Iturralde are noted with appreciation. Copyediting services were provided by Sydney Preston and Anya Wohlgemuth, translation services by Anne Glatz, Mark Fallak and Markus Teubner.
} 


\section{EXECUTIVE SUMMARY}

The enormous inflow of foreigners and ethnic German immigrants, particularly over the past decade, has turned Germany into a de facto immigration country. What distinguishes Germany from "classical" immigration countries like Canada, however, is that it has only recently begun to react to this development with efforts to establish comprehensive immigration legislation. The immigration act passed by the German Bundestag and Bundesrat in March 2002 could mark a turning point in German immigration history - even if the Federal Supreme Court decides that the passing of the bill in the Bundesrat was unconstitutional or a post election parliament forces a review.

\section{I.}

The absence of a systematic German immigration law appears to be one of the reasons for the fragmented nature of most government-sponsored integration programs. One of the obvious deficits of the German system is that a consistent strategy to encourage second language acquisition among immigrants has yet to be developed. Ethnic German immigrants must pass a language test prior to their arrival in Germany, but this test applies only to primary applicants, not to family members. For the larger group of non-German immigrants, there is no mandatory language test, nor does a comprehensive and widely used language-training program exist. This shortfall contributes to the language barrier between immigrants and German natives, which ultimately has a negative impact on social and labour market integration.

A fundamental change in this unsatisfactory situation is about to occur. In fact, since 2000, everyone who is legally entitled to obtain German citizenship has had to prove sufficient language skills as a prerequisite to naturalization. This is the first sign of a changing attitude toward second language acquisition as an important integration tool. Moreover, German language policy is bound to undergo a substantial reform with the introduction of a new "comprehensive language concept" (Gesamtsprachkonzept), which is an attempt to integrate the existing different immigrant streams into a single program. More importantly, language knowledge as a selection criterion and integration tool has been included in the new immigration act. This should lead to a growing share of new immigrants with at least a basic proficiency in German. The new immigration act requires that in the future family members of ethnic German immigrants will also have to furnish proof of sufficient language proficiency in order to obtain a visa.

In contrast to Germany, Canada has a comprehensive immigration policy as well as a strategy of immigrant second language acquisition tailored to the Canadian interests. There is ample reason to believe that the Canadian model recently adapted by German policymakers, in 
which language skills are part of a "point system" for selecting immigrants, could pave the way for a successful German "model".

II.

Canada has actively recruited immigrants for almost a century, under explicit immigration legislation. Canada's modern immigration policy, which was introduced in 1967, is based on a "point system" which assesses applicants according to objective criteria such as age, education, work experience, and language. This was the first explicit use of language skills as a selection criterion in Canada. However, it is not necessary to score any points in the language category to successfully qualify as a landed immigrant. Furthermore, ascension to Canadian citizenship only requires a limited knowledge of one of Canada's two official languages. What are the lessons of Canada's laissez-faire immigrant language policy? The answer to this question is the primary focus of this study. It traces Canada's and Germany's immigration history and language policy as well as the effectiveness of the models of second language acquisition in both countries. This analysis in turn provides positive and negative lessons for German immigration policy initiatives.

Canada's immigration policy has changed dramatically over the last thirty years from a primarily points-based economic assessment program (1967-73) to a family reunification admission policy (1980s) to its currently balanced economic and family admissions immigration policy. As Canada immigration policy has evolved the language component in its selection process has increased in importance. Canadian policy-makers now recognize that recruiting immigrants who are fluent in one (or both) of the official languages facilitates social integration and insures a more successful economic outcome. Currently, about 95 percent of successful applicants in the skilled worker category possess a working knowledge of one official language. However, language requirements for citizenship are extremely low with only basic English (or French) oral language skills required at most. Although minimal official language screening appears at the point of entry, language proficiency is continuously assessed throughout the individual's stay in Canada. In fact, the individual's success in the Canadian labour market is ultimately based on his/her degree of second language acquisition.

III.

Germany, unlike Canada, has not officially considered itself an immigrant receiving country until now and has even hesitated to consider this concept during the most recent debate which led to the first immigration act in German legal history. Germany's migrant inflow includes nonethnic foreigners or Ausländer as well as ethnic Germans or Aussiedler whose families lived in East or Southeast Europe for generations and who have maintained a "German" identity via descent, language, and culture. Ausländer were initially recruited during the labour shortages of the 1950s as "guest workers". As a result, almost half of all "German" foreigners have lived in the country for more than one or even two decades with second- and third-generation families of former "guest workers" in Germany. The original "guest workers" today are no longer the 
majority of foreigners in Germany. Today, their children, most of whom are born in Germany, and new immigrants, especially from eastern Europe, are the majority. Thus, the integration of foreigners within now a different context will once again prove to be an important issue.

The social and labour market situation of Ausländer is to a large extent comparable to the situation of Aussiedler in Germany. The same applies to potential new foreign or ethnic German immigrants. Most ethnic Germans still living in Eastern Europe are members of the second and subsequent generations who have had no direct contact with Germany. The large influx of immigrants during the last decade has led to considerable integration problems. Difficulties of social cohesion have surfaced, sometimes evoking xenophobia. At least in part, these problems are due to their lack of language skills. As a result of drastically increasing numbers of immigrants applying for Aussiedler status, language tests were introduced in the 1990s in order to insure a better evaluation of their case. These language tests have identified an inherent lack of language proficiency for a large number of Aussiedler.

IV.

In the Canadian context the plethora of Canadian immigrants with inadequate language skills, has led to a private sector response with a variety of English (and French) as a Second Language (ESL/FSL) teaching institutions. Language courses are based on the Canadian Language Benchmarks Assessment (CLBA) developed by the government to unify standards for language instruction. The primary course of instruction is called Language Instruction for Newcomers to Canada (LINC). These courses are government-sponsored and available to all successful new immigrants through a variety of not for profit private outlets Language training is provided for up to three years. It is hoped that this time frame will allow the learner to gain sufficient language skills to meet family, employment, and other social obligations.

Unlike Canada's training sector, the German language instruction system is governmentdominated. The German government funds language-training courses for both Aussiedler and Ausländer. The goals of these courses are to facilitate economic and labour market integration to improve social contacts, and to increase political and cultural participation. Funding for the two entry groups is governed by different agencies. Success rates for these programs are deemed high, according to surveys conducted about their effectiveness. However, these survey results are self-reported by service providers; participants and have not been empirically tested.

A new "Gesamtsprachkonzept" will unite previously separated language programs for Aussiedler and Ausländer into one official language training program for all new permanent immigrants. The regulations that are incorporated in the new immigration act clearly show that the separate treatment of Aussiedler (language test prior to entry) and Ausländer (language course offers after entry) will not be discarded altogether. Indirectly, however, the immigration act creates an incentive to acquire language skills before application or entry - language skills are assessed within the point system, legal entitlement to naturalization is offered one year earlier 
after attending an integration course, and attendance of language and integration courses is compulsory if the applicant is not able to communicate in German "on a basic level".

$\mathrm{V}$.

In essence, two distinct models of second language acquisition exist in the two countries however, given recent legislative activity in Germany and Canada, convergence is appearing. Canada does not require immigrants to learn either official language at any point from entry to citizenship. Only indirectly does Canada's recently modified point system aim at selecting immigrants with stronger language skills. It could be argued that the Canadian model relies on a market solution to achieve optimal second language acquisition by immigrants after their admission. Germany, on the other hand, explicitly uses second language acquisition as a screening device for Spätaussiedler and a criterion for citizenship for both Spätaussiedler and Ausländer. The new immigration act has also created the legal basis to assess language skills within a point system before entry. In addition, a myriad of state agencies offer subsidized language training through a variety of programs to facilitate integration into society.

A theoretical framework for measuring optimal immigrant second language acquisition across a variety of activity milieus (economic, social, educational, and political) suggests that not one level of immigrant second language acquisition is sufficient in any one sphere. Within each sphere, individuals will voluntarily acquire (in the absence of a subsidy or government compulsion) a mix of second language skills, depending on their individual characteristics. In a voluntary system of language acquisition (in the absence of subsidies), the default equilibrium second language acquisition in the labour, political, and social spheres will be minimal oral second language skills. This dramatic shortcoming can be overcome with a loan program for second language acquisition. Under these conditions, a skilled or professionally qualified immigrant who receives a loan would obtain a degree of language proficiency that $\mathrm{s} / \mathrm{he}$ regards as beneficial in the social, labour, and political spheres. In particular, in the labour market this loan scheme must be sufficiently generous to enable the immigrant to acquire second language skills to pass the appropriate qualifying exams.

VI.

The main advantage of the Canadian voluntary system is that an optimal level of second language acquisition by the young and financially able will occur because the immigrant perceives second language acquisition as an investment that will be rewarded in the labour market. S/he will continue to acquire second language proficiency until this investment on the margin is no longer rewarding. In the event that discrimination or macro labour market conditions (unemployment) prevent the immigrant from realizing his or her return, the contingent nature of the repayment scheme removes any risk. 
Certification of results, training appropriate for the task at hand, and employer recognition are essential ingredients under a voluntary program. In the absence of any of these, any individual immigrants will not make an optimal investment in second language acquisition because their expected rewards will not be realized.

In Germany, the statist model of second language acquisition would be a logical solution if the only policy objective were naturalization of all immigrants, Aussiedler as well as Ausländer. However, if German immigration policy aims at controlling immigration by means of a selection process, a modified version of Canada's second language acquisition model seems appropriate. In the German context it is not sufficient, though, to rely solely on voluntary language acquisition. The acquisition of a certain degree of proficiency in German at an early stage after entry appears to be desirable for several reasons. Canada's laissez-faire policy works because English, one of the two official languages, is an international language, which means that it is fairly likely that immigrants possess at least some knowledge in English prior to arrival. For Germany, the reverse is true. Furthermore, the incentive to acquire knowledge of German is comparatively low if further migration, e.g. to the US or Canada, is planned. Also, given the greater influx of immigrants into Germany, the resulting integration problems cannot be solved exclusively by voluntary in-country language acquisition - additional measures are essential for successful integration. The sooner immigrants meet basic German language standards, the faster social integration will occur. In this regard, the evaluation of language skills in the point system included in the new German immigration act seems to be a plausible solution. Within such a system it is vital, though, not to give too much weight to language proficiency. An exclusive focus on language would divert the "best brains" to migrate elsewhere where there exist less stringent language requirements.

After entry into Germany, a voluntary second language acquisition model appears to be a realistic approach to meet both the individual's needs and the common interest in facilitating social integration. In addition, an incentive structure modeled after Australia could be introduced before naturalization to hasten German language acquisition. Under this system an immigrant who fails the initial language test would have to pay such a deposit, which would be fully refunded if the immigrant successfully passes a language course or a second test within a given period of time. A government guaranteed loan scheme for these prospective students would both give an incentive to learn and allow private language schools to emerge.

Finally a delicate balance between incentives and standards for German language acquisition must be put in place to maintain Germany's attractiveness as a destination country. The existence of comprehensive German immigration legislation will enable authorities to insure this balance by selecting immigrants according to a point system favouring language knowledge. Thus, the proposed requirement for applicants who lack minimal oral language proficiency to attend language and integration courses, which is provided for in the new immigration act, may not be effective. It would make more sense to link language course attendance to positive learning incentives for all immigrant groups. 
In sum, a reformed German immigrant language policy for Germany could combine the Canadian and the German models with explicit minimum standards (German) and the principle of voluntary participation with financial incentives (Canadian) to both hasten and improve the process of immigrant second language acquisition. German society - both foreigners and Germans - will benefit from this mixed strategy of mandatory and voluntary language requirements. 


\section{$\underline{\text { Table of Contents }}$}

Introduction

A. Canadian Immigration Policy - Post 1945

B. Canada's Citizenship Act and Language Requirements 10

C. Historical Development of Germany's Immigration Policy 14

D. Confirmation of German Citizenship 21

E. Aussiedler Language Tests 25

F. Canada's Market-Based Language Tests and Instruction 30

G. Canada's Language Benchmarks 34

H. German Language Training 38

I. Evaluation of Second Language Acquisition in Canada and Germany 54

$\begin{array}{ll}\text { Summary and Conclusion } & 60\end{array}$

$\begin{array}{ll}\text { References } & 66\end{array}$

Appendix A

Excerpts from the German Grundgesetz/Basic Law 70

\section{Appendix $B$}

Excerpts from the General Administrative Provisions to the

German Citizenship and Naturalization Law - StAR-VwV

(as of January 1, 2000), Cabinet Decision, October 18, 2000

\section{Appendix $C$}

Excerpts from the German Law on the Control and Limitation

of Immigration and the Regulation of the Stay and Integration of

EU Citizens and Foreigners (Immigration Act) of June 20, 2002

Appendix D

Language Support Program for Ethnic Germans

and Foreigners in Germany, Status 2000

Appendix E

Excerpts from Bill C-11 (Canada's Immigration and Refugee Protection Act) 


\section{$\underline{\text { Tables and Figures }}$}

Table 1: Immigrants to Canada by Region of Last Permanent Residence: 1967-2000 6

Table 2: Language Assessment Guide 8

Table 3: Migration of Foreigners into and out of Germany 1991 to $1999 \quad 18$

Table 4: Results of Language Tests for Spätaussiedler 27

Table 5: Overview of Language Requirements in Different Phases of Immigrants' Residence in Canada 31

Table 6: General Content of Canadian Language Benchmarks 35

Table 7: Entries of Spätaussiedler in German language courses 1991-1997 41

Table 8: Space of Time Between Arrival and Entry into Language Courses 44

Table 9: Space of time Between Arrival and Entry into GF-SB Language Courses 46

Table 10: Ausländer Motivations for Participation in a German Language Course $\quad 50$

Table 11: Rates of Return Based on Second Language Proficiency in Canada 55

Figure 1: Net Migration, Influx into and Migration Outflow out of Germany, 1995-2000 14

Figure 2: Influx of (Spät)Aussiedler into Germany 1950-2000 16

Figure 3: Population of Aussiedler and Ausländer in Germany, 1951-1998 19 


\section{Introduction}

Today, 7,3 million foreigners reside in Germany and comprise almost 9 percent of the German population. Furthermore, ethnic Germans have immigrated to Germany from Eastern Europe for many years, most of whom have hardly any relationship to their new home country. Consequently, Germany could be classified as a country shaped by immigration. Even though these two arrival groups - Ausländer (foreigners), who do not hold German citizenship, and Aussiedler or Spätaussiedler (ethnic Germans) ${ }^{1}$, who do - are treated very differently under German law, their integration problems are ultimately similar. In particular, there often exists a substantial language barrier between native Germans and both Aussiedler and Ausländer. These linguistic problems may create social as well as economic tensions between German nationals and Germany's immigrant population.

Partly in recognition of this problem, but mainly in order to decrease the influx of ethnic Germans, a language test was instituted in 1996 for ethnic Germans applying for the status of Spätaussiedler. Since 1996 applicants must pass a language test in order to obtain Spätaussiedler status and a visa. Until now, their family members do not have to pass this test. For the first time, a language criterion was thereby legally established as a selection mechanism for a large ethnically German - group of immigrants. However, this did not lead to further debate on language assessment for all foreigners, primarily because no legal basis for an immigration act existed. But when discussion arose concerning a substantial reform of the German naturalization law, language skills as an integration issue for all arrivals emerged. This political debate has resulted in a reformed German naturalization law, in effect since January 1, 2000, which for the first time includes a language criterion as a precondition to file a legal claim for citizenship.

Only after 1998 has the ongoing discussion in Germany begun to concentrate on a rationale for a more rigorous language test for Spätaussiedler (and family members) as well as the practicality of a uniform language-training program for all immigrants entering the country. While German language policy can still be classified as fragmentary, language is now increasingly perceived by German policy-makers as a means of integrating previous and new

\footnotetext{
${ }^{1}$ After 1992, the term Aussiedler was changed to Spätaussiedler. This study uses both terms synonymously.
} 
Aussiedler and Ausländer arrivals into German society and the labour market. After fierce political controversy, the Gesetz zur Steuerung und Begrenzung der Zuwanderung und zur Regelung des Aufenthalts und der Integration von Unionsbürgern und Ausländern (Zuwanderungsgesetz) (Law on the Control and Limitation of Immigration and the Regulation of the Stay of Foreigners and Integration of EU Citizens and Foreigners - Immigration Act), which was introduced by the federal government in November 2001, was passed by the German Bundestag (Parliament) and the German Bundesrat (Upper House) in the spring of 2002. ${ }^{2}$ The law, which presumably will come into effect on January 1, 2003 (the provisions that are most important for this analysis are documented in Appendix C), is not only intended to provide a new legal basis for the entry of foreigners along with a systematic immigration procedure for highskilled labour. It also aims at making language competence an entry requirement and adopting a Canadian-style point system to assess the language skills of prospective immigrants.

At the same time, a mandatory "integration course" for those new immigrants who are not able to communicate in German "in a basic way" is introduced by the immigration act. However, the act also modifies the legal requirements for citizenship: Successful attendance of this kind of government-sponsored language course offers legal entitlement to naturalization already after seven (instead of eight) years of residence. The immigration act now also provides that family members of applicants for Spätaussiedler status have to furnish proof of sufficient language proficiency as a precondition for obtaining a visa and that they are entitled to attend an integration course in Germany for free. However, despite the expected entry into force of these provisions on January 1, 2003, the debate about second language acquisition of immigrants is likely to continue..

The implementation of language tests for Spätaussiedler leads to several key questions: Should one single German language standard be applied to both Aussiedler and Ausländer? Moreover, should the test be applied at the point of entry or later - during the process of social

\footnotetext{
${ }^{22}$ Cf. Bundesgesetzblatt (Federal Law Gazette), part 1, No. 38, June 25, 2002, 1946-2000 for the official version of the first German immigration act. The bill was passed by the German Bundestag (Parliament) on March 1, 2002 and the German Bundesrat (Upper House) on March 22, 2002 in a voting process that is still very controversial with regard to its constitutionality. Although the German Bundespräsident (Federal President) signed the immigration act on June 20, 2002, opposition in parliament could appeal to the Bundesverfassungsgericht (Federal Supreme Court) to decide whether the process in which the law came about was constitutional. After election day on September 22, 2002, a new majority in parliament could again force a revision of the law.
} 
integration or prior to naturalization? Also, how much language is enough? Should the standard be uniform, or should it be responsive to individuals' needs? And what about labour market issues? Should the language standard match the entry point into the labour market?

German politicians and society in general have only just begun to face these crucial questions. To date, it has been acknowledged that some German language skills are essential at all levels of society, but no comprehensive strategy has been developed yet which addresses these issues. A new Gesamtsprachkonzept (general language concept), though, is to be expected in the near future (the new immigration law already points in this direction). It will be an attempt to combine all areas of language training in order to create a more transparent and uniform language-training program and is meant to include all immigrants, Ausländer and Aussiedler. In contrast, Canada has actively recruited immigrants for over a century, since 1911 under explicit immigration legislation. Canada's modern immigration policy, introduced in 1967, selects immigrants regardless of their language proficiency. In fact, immigration is possible even if the applicant has no knowledge of either of Canada's two official languages. The lack of language skills can be compensated by high performance in other parts of the point system. ${ }^{3}$

This remains true, although new entry regulations were passed by the Canadian parliament in November 2001 which put more emphasis on language criteria. Furthermore, ascension to Canadian citizenship only requires a limited proficiency in one of the two official languages. What are the lessons of Canada's laissez-faire immigrant language policy, and are they applicable to the case of Germany with respect to its immigration policy? The answer to this question is the primary focus of this study. In the following, Canada's and Germany's immigration histories and language policies as well as the effectiveness of the models of second language acquisition in both countries are traced and analyzed.

${ }^{3}$ CIC (1998), 56-59. 


\section{A. Canadian Immigration Policy - Post $1945^{4}$}

Canada has traditionally used immigration as an engine of economic and population growth. Between the 1890s and 1920s, Canada actively recruited farmers and farm workers to help settle the western part of the country. To maintain a homogeneous culture, Canada's immigration policy targeted immigrants from Britain, the United States and later Northwest Europe, which also limited the need for language training.

This rather exclusive and racist immigration policy was maintained until after World War II when labour shortages increased the demand for foreign labour. As immigration from Britain and the United States began to decrease, Canada sought immigrants from Southern and Eastern Europe. Despite this change in focus, restrictions against Asian immigrants remained. ${ }^{5}$ A major shift in this attitude occurred in 1951, when the Canadian government introduced "small but symbolically important quotas for its non-white Asian Commonwealth partners, India, Pakistan, and Ceylon." The 1911 Immigration Act was revised in 1952, placing a greater emphasis on family reunification by widening the provisions for sponsorship rights. ${ }^{6}$ The result of this policy revision was a large increase in the pool of skilled and semi-skilled labour, which supplied the resource, construction, and manufacturing sectors. ${ }^{7}$.

This large new immigrant inflow in conjunction with an economic downturn in the 1960s led to a major immigration policy shift in 1962, when all independent applicants were evaluated "on the basis of individual skills, or, more precisely, Canadian market needs". ${ }^{8}$ Again, language skills were not an issue; however, it was also not specified which skills were needed, and the vagueness of the directive left considerable discretionary power in the hands of immigration officers.

\footnotetext{
${ }^{4}$ This section provides only a rudimentary review of Canada's immigration policy. For a more detailed account see Green/Green (1996) or Chiswick (1992).

${ }^{5}$ This can be seen in a statement given by Prime Minister Mackenzie King before the House of Commons in 1947: “...There will, I am sure, be general agreement with the view that the people of Canada do not wish, as a result of mass immigration, to make a fundamental alteration in the character of our population. Large-scale immigration from the Orient would change the fundamental composition of the Canadian population..." (Green/Green 1996, 13).

${ }^{6}$ However, restrictions on Asian immigrants even in the family reunification category remained in place. These and all other racist features of the 1952 Immigration Act were not removed until 1967.

${ }^{7}$ Green/Green (1996), 16.

${ }^{8}$ Chiswick (1992), 33.
} 
This vagueness in assessment led to the introduction of the "point system" in 1967, which assessed applicants according to objective criteria such as age, education, work experience, and language. This was the first explicit use of language skills as a selection criterion. Applicants now had to obtain a total of at least 50 points, of which a maximum of 10 points could be earned by knowledge of one or both of the official languages. This emphasis on human capital characteristics now biased immigration selection towards highly trained immigrants and effectively eliminated all preferences for specific national groups.

The result was a "new immigration wave", and after 1968 Canada's immigrant origin composition changed drastically (cf. Table 1). Prior to 1968, immigrants from Europe and the United States to Canada comprised almost three-quarters of all Canadian immigrants. By 199196, the immigrant inflow from Europe and the United States had dwindled to less than one quarter. In contrast, immigrant levels from Asia, Africa and Latin America increased dramatically. Immigration levels from Asia grew from 13 percent (1968) to 57 percent (1996). Immigration levels from the Caribbean increased from 5.5 percent to over 13 percent of the total between 1968 and 1986, but then declined back to their original levels in the 1990s. Latin American immigrants constituted less than 1 percent of all immigrants in 1968, but in 1986 they had jumped to almost 9 percent. Lastly, Africa sent less than 4 percent of all immigrants in 1968, but by 1996 the proportion had almost doubled to 7.3 percent.

\footnotetext{
${ }^{9}$ Simmons (1990), 141.
} 
Table 1: Immigrants to Canada by Region of Last Permanent Residence: 1967-2000

\begin{tabular}{|c|c|c|c|c|c|c|c|c|c|c|c|}
\hline YEAR & Europe & Africa & $\underline{\text { Asia }}$ & stralia & U.S.A. & $\begin{array}{r}\text { Other } \\
\underline{\text { North/ }} \\
\underline{\text { Central }} \\
\underline{\text { America }}\end{array}$ & Caribbean & $\underline{\begin{array}{r}\text { South } \\
\text { America }\end{array}}$ & $\frac{\frac{\text { Oceania }}{\& \text { other }}}{\underline{\text { Ocean }}}$ & $\underline{N S}^{\mathrm{a}}$ & $\frac{\text { GRAND }}{\text { TOTAL }}$ \\
\hline 1967 & 159,979 & 4,608 & 20,740 & 6,168 & 19,038 & 422 & 8,582 & 3,090 & & 49 & 222,876 \\
\hline 1968 & 7 & & & & & 374 & & 2,693 & & 323 & \\
\hline 1969 & & 3,297 & 23, & 4,411 & 22 , & 593 & & 4,767 & & 681 & \\
\hline 1970 & 5,609 & 2,863 & 21,170 & 4,385 & 24,424 & 711 & 2,660 & 4,385 & & 948 & 713 \\
\hline 1971 & & 28 & & & & 636 & & 2,902 & & 878 & \\
\hline 1972 & ,293 & 8,308 & 23,3 & 2,143 & 22 & 865 & & 2,143 & & 792 & 006 \\
\hline 1973 & 71,883 & 8,307 & 43,193 & 2,671 & 25,242 & 1,141 & 63 & 11,057 & 5 & & 200 \\
\hline 1974 & & & & & & 91 & & & & & \\
\hline 1975 & & & 32 & & & 1,510 & & 70 & 52 & & \\
\hline 1976 & 908 & 7,752 & 44,328 & & 17 & 56 & & 10,628 & 1,414 & & 429 \\
\hline 1977 & & & & & & 30 & & & 912 & & \\
\hline 1978 & & & & & & 950 & & & 719 & 13 & \\
\hline 1979 & & & 50 & & & 732 & & & 726 & 6 & \\
\hline 1980 & & & & & & & & & 942 & & \\
\hline 1981 & & & & & & & & & 934 & 17 & \\
\hline 1982 & & & & & & & & & 81 & 196 & \\
\hline 1983 & & & & & & & & & 735 & & \\
\hline & & & & & & & & & 616 & 25 & \\
\hline 19 & & & & 5 & & & & & 622 & & 302 \\
\hline & & & & & & & & & 724 & & 219 \\
\hline & & & & & & & & & & 2 & \\
\hline 19 & & & & & & 71 & & 25 & 77 & & 929 \\
\hline & & & & & & & & & & 49 & \\
\hline & & & & & & & & & & 7 & \\
\hline 1991 & & & & & & 04 & & & & 44 & \\
\hline 1992 & & . & & & & & & & 2,468 & 59 & 842 \\
\hline 1993 & 46,602 & 6,918 & & & & & & & 1,763 & & \\
\hline 1994 & & & & & & & & 7,919 & 1,197 & & \\
\hline 1995 & & 4,631 & 129,106 & & & & & 7,538 & 831 & & 504 \\
\hline 1996 & 39,970 & 14,859 & 144,210 & 1,228 & 5,837 & 3,409 & 9,322 & 6,104 & 834 & & 225,773 \\
\hline $7-85^{b}$ & 132,746 & 102,571 & 703,167 & 13651 & 06,243 & 28,320 & 08,196 & 119,778 & 14,412 & 12 & $2,667,878$ \\
\hline $6-96^{b}$ & 462,416 & 44,123 & $1,216,462$ & 10,730 & 74,198 & 75,694 & 125,933 & 94,498 & 14,957 & 161 & $2,221,071$ \\
\hline $7-96^{b}$ & $\underline{1,595,162}$ & 46,694 & $1,919,629$ & $\underline{54,381}$ & 380,441 & $\underline{104,014}$ & 334,129 & 214,276 & 29,369 & 4,289 & $4,888,949$ \\
\hline
\end{tabular}

\begin{tabular}{|c|c|c|c|c|c|c|c|}
\hline Year & Europe and UK & $\underline{\text { Middle East }}$ & Asia \& Pacific & $\frac{\text { South/Central }}{\underline{\text { America }}}$ & $\underline{\text { United States }}$ & $\mathrm{NS}^{\mathrm{a}}$ & $\frac{\text { GRAND }}{\text { TOTAL }}$ \\
\hline 1997 & 38,670 & 37,792 & 117,064 & 17,422 & 5,028 & 38 & $\overline{216,014}$ \\
\hline 1998 & 38,516 & 32,567 & 84,125 & 14,031 & 4,768 & 152 & 174,159 \\
\hline 1999 & 38,912 & 33,441 & 96,370 & 15,188 & 5,514 & 391 & 189,816 \\
\hline 2000 & 42,875 & 40,779 & 120,491 & 16,939 & 5,809 & 316 & 227,209 \\
\hline $97-00^{b}$ & 158,973 & 144,579 & 418,050 & 63,580 & 21,119 & 897 & 807,198 \\
\hline $67-00^{b}$ & $\underline{1,754,135}$ & $\underline{N / A}$ & $\underline{N / A}$ & $\underline{N / A}$ & 401,560 & 5,186 & $5,696,048$ \\
\hline \multirow[t]{2}{*}{ Sources: } & $\begin{array}{l}\text { Citizenship and } \\
\text { Citizenship and }\end{array}$ & $\begin{array}{l}\text { migration } \mathrm{Ca} \\
\text { migration } \mathrm{Ca}\end{array}$ & $\begin{array}{l}\text { nada: Calendar } \\
\text { nada: Facts and }\end{array}$ & $\begin{array}{l}\text { ars } 1967-\overline{1996} \\
\text { gures 2000: In }\end{array}$ & grc & & \\
\hline & $\begin{array}{l}\text { Not state } \\
\text { Represe1 }\end{array}$ & cumulativ & lows for the 1 & tive years & & & \\
\hline
\end{tabular}


The 1978 Immigration Act introduced for the first time a yearly quota and defined specific goals for immigration including meeting Canadian economic and demographic needs, family reunification, and honouring Canada's humanitarian refugee obligations. It has been argued that "the 1978 Immigration Act substantially altered the entry gateways to Canada since during the 1968-76 period (under the 1953 Immigration Act) over 70 percent of immigrants were screened in the economic or independent class. This percent dropped under the 1978 Immigration Act at first below 30 percent (1975-82) and then to about 14 percent of the total flow by the mid-1980s." $" 10$ This rapid decline in the economic entry class was in no small part due to the fact that the yearly quota was an overall quota that did not distinguish between the different types of immigrants (family, refugee, or economic class). Thus, when economic immigrants were not available, Canadian officials simply expanded the number of family class entrants.

The system was once again revised in the 1990s to increase the number of economic immigrants and their qualifications. As of January 2000, to enter Canada as an economic immigrant, one had to accumulate at least 70 points out of a total of 107 . The points were distributed as follows. A maximum of 15 points is given for language - a maximum of 9 points for knowledge of one of the official languages, and a maximum of 6 points for knowledge of the other official language. Language skills thus accounted for less than 10 percent of the maximum number of points. The language knowledge is self-assessed by the applicant. It is important to note that it is not mandatory to score any points in this language category in order to qualify for landed immigrant status, but it facilitates the achievement of the required number of points. In addition, a number of cases are interviewed to test the applicant's claim of language ability. These interviews are conducted in English or French by locally hired staff. ${ }^{11}$ Moreover, language also indirectly enters the assessment process as a secondary criterion when language is again used as a measure to assess the applicants' ability to integrate into Canada.

Examiners assess an applicant's language ability according to an assessment guide, which ensures a level of nominal consistency across interviews. Table 2 reproduces the main features of this guide.

\footnotetext{
${ }^{10}$ DeVoretz/Laryea (1997), 8.
} 
Table 2: Language Assessment Guide

\begin{tabular}{|l|l|l|l|}
\hline Skill/Level & Speak & Read & Write \\
\hline Fluently: & $\begin{array}{l}\text { The applicant speaks } \\
\text { and understands oral } \\
\text { communication with } \\
\text { approximately the same } \\
\text { ease as that of an } \\
\text { articulate native speaker. }\end{array}$ & $\begin{array}{l}\text { The applicant reads } \\
\text { and understands texts } \\
\text { of a general or job } \\
\text { specific nature, } \\
\text { including technical } \\
\text { instructions. }\end{array}$ & $\begin{array}{l}\text { The applicant writes } \\
\text { proficiently in any } \\
\text { context. }\end{array}$ \\
\hline Well: & $\begin{array}{l}\text { The applicant is able to } \\
\text { comprehend and to } \\
\text { communicate effectively } \\
\text { on a range of general } \\
\text { topics. }\end{array}$ & $\begin{array}{l}\text { The applicant is able } \\
\text { to comprehend almost } \\
\text { all documents of a } \\
\text { general, non-abstract } \\
\text { nature. }\end{array}$ & $\begin{array}{l}\text { The applicant is able } \\
\text { to write a basic report } \\
\text { or summary relevant } \\
\text { to their education, } \\
\text { work, or social } \\
\text { situation. }\end{array}$ \\
\hline $\begin{array}{l}\text { With } \\
\text { Difficulty: }\end{array}$ & $\begin{array}{l}\text { The applicant is able to } \\
\text { communicate only in a } \\
\text { very limited way. }\end{array}$ & $\begin{array}{l}\text { The applicant is able } \\
\text { to read and } \\
\text { comprehend only } \\
\text { short, familiar, or } \\
\text { memorized text. }\end{array}$ & $\begin{array}{l}\text { The applicant is able } \\
\text { to write only a few } \\
\text { learned words or } \\
\text { sentences of a } \\
\text { familiar nature. }\end{array}$ \\
\hline Not at all: & $\begin{array}{l}\text { The applicant is unable } \\
\text { to understand and } \\
\text { respond appropriately to } \\
\text { spoken communication. }\end{array}$ & $\begin{array}{l}\text { The applicant shows } \\
\text { no understanding of } \\
\text { the written word. }\end{array}$ & $\begin{array}{l}\text { The applicant is } \\
\text { unable to express any } \\
\text { message in writing. }\end{array}$ \\
\hline
\end{tabular}

Source: CIC Overseas Processing Manual, Internal Document, Citizenship and Immigration Canada.

The Citizenship and Immigration (hereafter CIC) publication, Canada's Overseas Processing Manual furthermore states that "[while] language ability would normally have been assessed during an interview, other factors may be considered, including: study or work experience in an English or French speaking country; work experience with an English or French organization; and evidence of language courses. The potential to function in the intended occupation should be part of the assessment." Currently, about 95 percent of successful applicants in the skilled worker category possess knowledge of an official language. Dissatisfaction with the above procedure has led to a proposed alternative method of testing

\footnotetext{
${ }^{11}$ Personal interview by Don DeVoretz with Lynda Joyce, Citizenship and Immigration Canada, May 24,1999.
} 
language ability. Under this proposal, rather than waiting for an interview, applicants could take an officially recognized language test, such as the Test of English as a Foreign Language (TOEFL), in their home country and send in the results with their application. The interview would be waived if the test score were satisfactory. The cost of the TOEFL would be borne by the applicant and will vary by country due to local operating expenses, but is generally US\$100 or the equivalent in local currency. ${ }^{12}$ Germany currently has four permanent TOEFL test centres (Berlin, Frankfurt, Hamburg and Munich) and two temporary test centres (Düsseldorf and Freiburg).

In sum, Canada's immigration policy has changed dramatically over the last thirty years from primarily a points-based economic assessment program (1967-73) to a family reunification admission policy (1980s) to a current balanced economic and family admissions immigration policy. As Canada has changed both the entry-type and source country for its immigrants, the language component in its selection process has increased in importance. It is now recognized by Canadian policy makers that recruiting immigrants who are fluent in one (or both) of the official languages facilitates social integration and insures a more successful economic outcome.

The newest regulations for entry to Canada under the independent gateway or point system passed in November 2001 as Bill C-11 (see Appendix E). It subtly but strategically revamps the points awarded to language upon entry into Canada as an independent immigrant. The maximum number of points earned under the language criterion is now 20 points up from the extant 15 points. Since the total number of entry points remains constant two forces are put into action. First, the absence of language skills makes it more difficult to compensate under other criteria to enter as an independent immigrant. Next, the language grid has been restructured by quality of skill, so that in essence only highly functional abilities in either of Canada's official languages will earn you maximum points. In short, basic linguistic skills now earn no points.

Canada has reaffirmed its commitment that language is essential for the success as an independent immigrant under this new legislation. While not making a lack of linguistic knowledge a bar to entry, the current configuration almost reaches that level.

\footnotetext{
${ }^{12} \mathrm{http}: / /$ www.toefl.org offers more information on TOEFL. This study refers to the paper-based test; in addition a computer-based TOEFL (yet with a different point system) is available.
} 


\section{B. Canada's Citizenship Act and Language Requirements}

Although immigration to Canada is not a new phenomenon, becoming a Canadian citizen is. Even though Canada came into existence in 1867, its inhabitants were still regarded as British subjects until 1947. Furthermore, before 1914, the "Naturalization Act," also known as the "Local Act," required all male foreigners to "apply to a court of competent jurisdiction in the area of their residence and to satisfy the court that they possessed all the qualifications necessary for the acquisition of British subject status."13 However, this status was retained only while staying within Canada. Once outside the country, the British subject status would be lost. Until 1932, women automatically took on the nationality of their husbands regardless of their original nationality, i.e. a female British subject became a foreigner when she married a foreigner. The geographic restriction was eliminated in 1915. Now, once a person acquired British subject status, s/he would retain it even after leaving Canada.

On January 1, 1947, the first Canadian Citizenship Act was enacted. It was the first nationality statute that explicitly defined a British subject residing in Canada as a "Canadian citizen". Citizenship under the first Canadian Citizenship Act was deemed a "privilege granted at ministerial discretion". ${ }^{14}$ It was not until the second Citizenship Act, effective February 15, 1977, that citizenship became a right of anyone meeting the requirements set out in the law. All discriminatory undertones regarding ethnicity, sex, marital status, or nationality were removed. The 1977 Citizenship Act is in effect today, although major changes were made in 1999. To become a Canadian citizen, today, a person must be of legal age (18 years or older) and must have been physically present in Canada for three of the previous six years. ${ }^{15}$ The new residency requirement, which requires physical presence in Canada, has the potential indirect effect of improving the immigrants' language skills prior to citizenship.

In addition to the age and residency requirements, applicants for citizenship must have a minimum of English (or French) oral language skill, and possess an adequate knowledge of

\footnotetext{
${ }^{13}$ CIC (1999b).

14 CIC (1999b).

${ }^{15}$ Prior to November 25, 1999, residency was satisfied by owning residential property or a business.
} 
Canada and of the associated responsibilities and privileges of citizenship. ${ }^{16}$ The latter two are tested by means of a written multiple choice citizenship test in one of the two official languages. It is important to note that the citizenship tests are developed by the Centre for Applied Language Studies at Carleton University and are based on a study guide called A Look at Canada. A copy of this study guide is sent to all applicants with their application acknowledgement letter. All of the questions and answers on the citizenship tests are taken from A Look at Canada. The questions are phrased in plain and simple English (or French) and use vocabulary and key words from that document.

The rationale underlying this test is that immigrants should develop minimum language skills and a working knowledge of Canada in order to facilitate integration and identification with Canadian values. To meet the language requirement, applicants must demonstrate an understanding of basic spoken statements/questions in either official language and be able to respond orally or in writing. To demonstrate knowledge of Canada, applicants must have a general understanding of the rights and responsibilities of citizenship as well as Canadian history, geography, culture and government structure. This requirement is waived for applicants 60 years of age and older.

Presently, a citizenship judge evaluates the results of the citizenship test to determine whether an applicant meets the language and cultural knowledge requirements. If an applicant is unable to demonstrate sufficient knowledge of one of the official languages or of Canada through this written assessment test, applicants are normally invited to an oral interview with a citizenship judge. This opportunity is provided because literacy is not an official requirement of citizenship, and therefore applicants cannot be punished for possible literacy deficiencies.

After the residency requirement of three years is met, applications for citizenship are permitted and then take 10-12 months to process from the time of application to acceptance or rejection. The citizenship test is administered approximately 8-9 months after receipt of an application. The applicant is given at least two weeks advance notice of the test date. Immediately prior to the test, CIC staff will verify information on the applicant's file by asking the applicant questions to corroborate the basic personal information indicated on the application

\footnotetext{
${ }^{16}$ CIC (1999a), 4.
} 
form, e.g., What is your address? How long have you been in Canada? Show me your driver's licence. This initial interview is meant to both verify the applicant's identity and carry out a preliminary assessment of the applicant's listening and speaking skills. After the interview, the applicant takes the written test in one of the official languages. ${ }^{17}$ If the interview indicates that the applicant does not comprehend basic questions and/or has not received a pass mark on the written citizenship test following the interview, this information is relayed to the citizenship judge for consideration and the applicant is referred to the judge for a formal hearing.

The judge will then further assess the applicant for official language and/or knowledge proficiency. The knowledge-related questions are based on A Look at Canada. Questions regarding language proficiency are based on everyday occurrences. For example, the applicant must answer questions such as: "What kind of work do you do? Are you married? Do you have any children?" 18

According to CIC officials, "approximately 95 percent of applicants meet the language and knowledge requirements. Ninety percent pass the written test (without the assistance of an interpreter) and a further five percent pass the oral interview with a citizenship judge"19 ${ }^{\text {with the }}$ help of an interpreter. ${ }^{20}$ If the applicant is successful, the application is approved and the applicant is notified by mail about the ceremony date, usually after two to four weeks. If, however, the applicant fails the interview, his application is rejected. The applicant then has the right to appeal the judge's decision.

The delays in processing citizenship applications and the cost of the process under large immigration numbers in the 1990s has led CIC to a process of "looking at a number of longerterm initiatives with the goal of improving the way CIC assesses applicants for language. In addition to developing a separate language test, the department is considering the use of core competency certificates as a mechanism for meeting both language and knowledge requirements

\footnotetext{
${ }^{17}$ Applicants are given 30 minutes to complete the test, but usually they need less time.

${ }^{18}$ The applicant is not required to speak in grammatically correct fashion; s/he only has to demonstrate comprehension of the questions asked.

${ }^{19}$ Personal communication by Don DeVoretz with Susan Nicholson, CIC, Ottawa. September 22, 1999.

${ }^{20}$ However, the interpreter can only be used for the knowledge assessment, not the language assessment. An interpreter is allowed since some applicants may not possess enough language skills to adequately respond to the more complicated knowledge questions.
} 
without a test. Essentially, this would mean that clients would be able to submit, with a citizenship application, a document establishing that the person has already met the language and/or knowledge requirements."21

${ }^{21}$ Personal communication by Don DeVoretz with Susan Nicholson, CIC, Ottawa. September 22, 1999. 


\section{Historical Development of Germany's Immigration Policy}

Germany, unlike Canada, has not officially considered itself an immigrant receiver and has even hesitated to consider this concept during the most recent debate on a possible immigration act. Due to its economic strength, its social benefits and its central location in Europe, though, Germany has experienced a large influx of de facto immigrants and refugees. In the early years of the last decade, immigration numbers to Germany were higher than the sum of immigration to the U.S., Canada and Australia. During the first half of the last decade, up to 1.5 million foreigners annually entered the Federal Republic, amounting to a net migration of up to 800,000 (see Figure 1).

Figure 1: Net Migration, Influx into and Migration Outflow out of Germany, 1955-2000

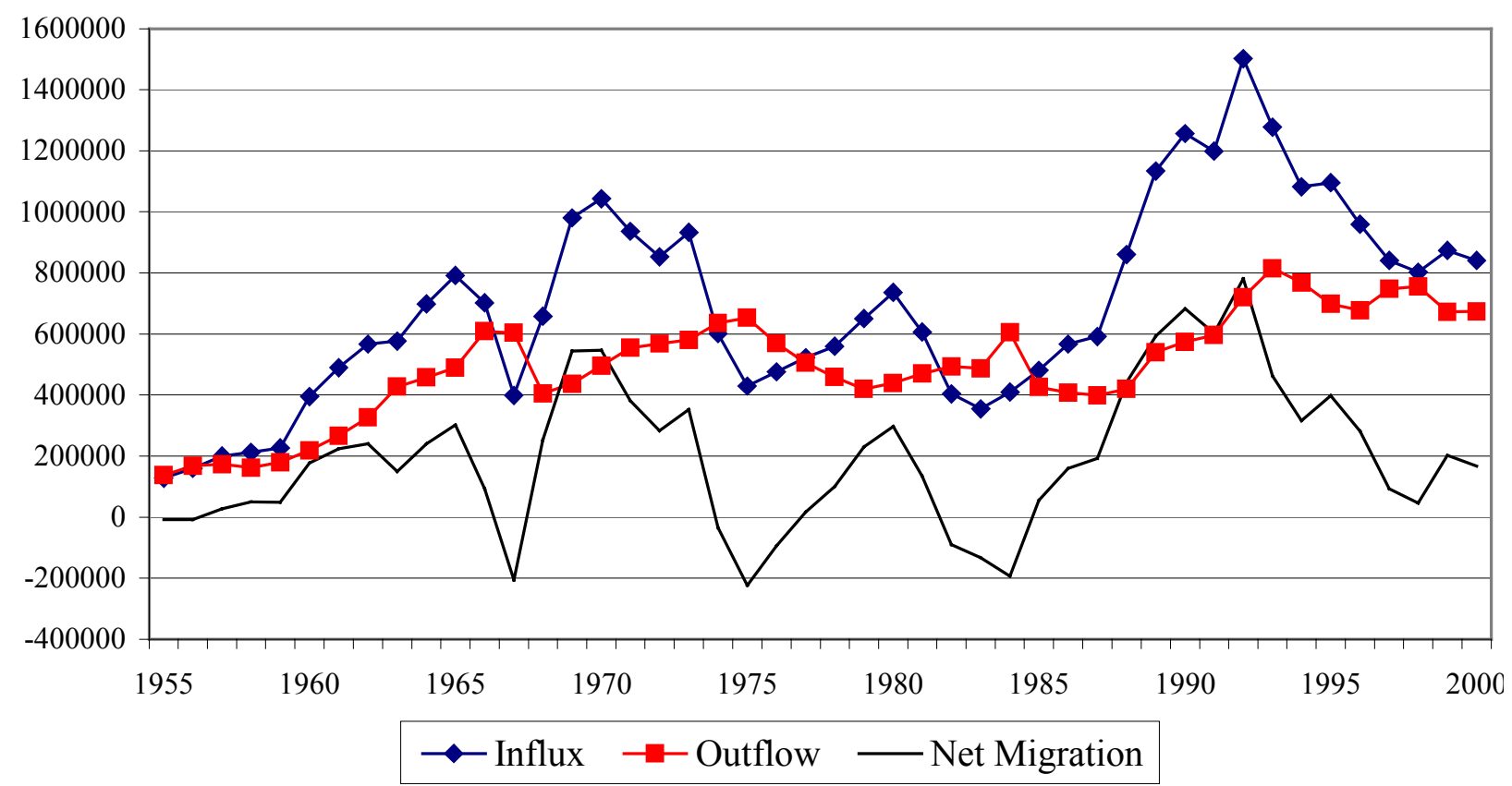

Source: Statistisches Bundesamt

The largest group of immigrants to Germany consists of Ausländer, who, due to the lack of an immigration law, have entered Germany on the basis of various legal arrangements (family reunification, Anwerbestopp-Ausnahmeverordnung, asylum seekers, civil war refugees, quota 
refugees, etc.). The second-largest group are ethnic Germans, or Spätaussiedler, and their families. The latter are defined as ethnic Germans whose families lived in East or Southeast Europe for generations (Russia, Romania) or were resettled to Poland during the Third Reich.

The history of the Aussiedler begins in the $18^{\text {th }}$ century, when a large number of Germans emigrated to Eastern Europe. ${ }^{22}$ These ethnic minorities became German citizens by virtue of "Germanization" laws that originated under Bismarck in the late $19^{\text {th }}$ century. After Germany's defeat in World War I and territorial losses, many of those Germans became foreigners. Finally, under the Third Reich Germany resettled Germans to its conquered eastern territories. At the end of World War II about 15 million German citizens became refugees or expellees. The first West German post-war census in 1950 revealed that almost 10 million expellees from the former German eastern territories now lived in Germany and made up nearly 20 percent of the population. From the 1950 s on, Germany negotiated treaties with several of the applicable countries to allow a proportion of remaining ethnic Germans to migrate to Germany. However, several hundred thousand German natives and their descendants continue to live outside of reunified Germany. Their precise number can only be estimated and depends on the exact recognition criteria used. Article 116 of the German Constitution (Grundgesetz) still continues to award Aussiedler German citizenship after immigration to Germany (see Appendix A). The German expellee legislation, the Bundesvertriebenen- und Flüchtlingsgesetz (BVFG), covers the details for the recognition and admission of these immigrants. In general, the law requires proof that the applicant has maintained a certain degree of German identity via descent, language, and culture. The same law deals with government programs to support integration for ethnic Germans, such as low-interest loans and language courses. ${ }^{23}$

In the early 1990s, ethnic Germans became increasingly ghettoized in Germany. Newly arrived Spätaussiedler settled with earlier Aussiedler, among whom were friends or relatives. Despite short-term economic gains from networks among ethnic Germans, a resulting negative integration signal and social tensions between Aussiedler and resident Germans were prevalent. The legislative response to this development was the Wohnortzuweisungsgesetz, or "Assigned

\footnotetext{
22 The following is based on Zimmermann (1999), 2-8.

${ }^{23}$ The legal and social equalization of Aussiedler is regulated mainly by the Lastenausgleichsgesetz (LAG, 1952), the Bundesvertriebenen- und Flüchtlingsgesetz (BVFG, 1953), and the Garantiefonds (1954).
} 
Place of Residence Act". This law, which has been in effect since 1996 and was renewed in 2000, ties welfare payments to a particular place of residence that is assigned to every Spätaussiedler, resulting in a decentralization of ethnic Germans at the cost of their mobility.

Figure 2: Influx of (Spät)Aussiedler into Germany 1950 - 2000

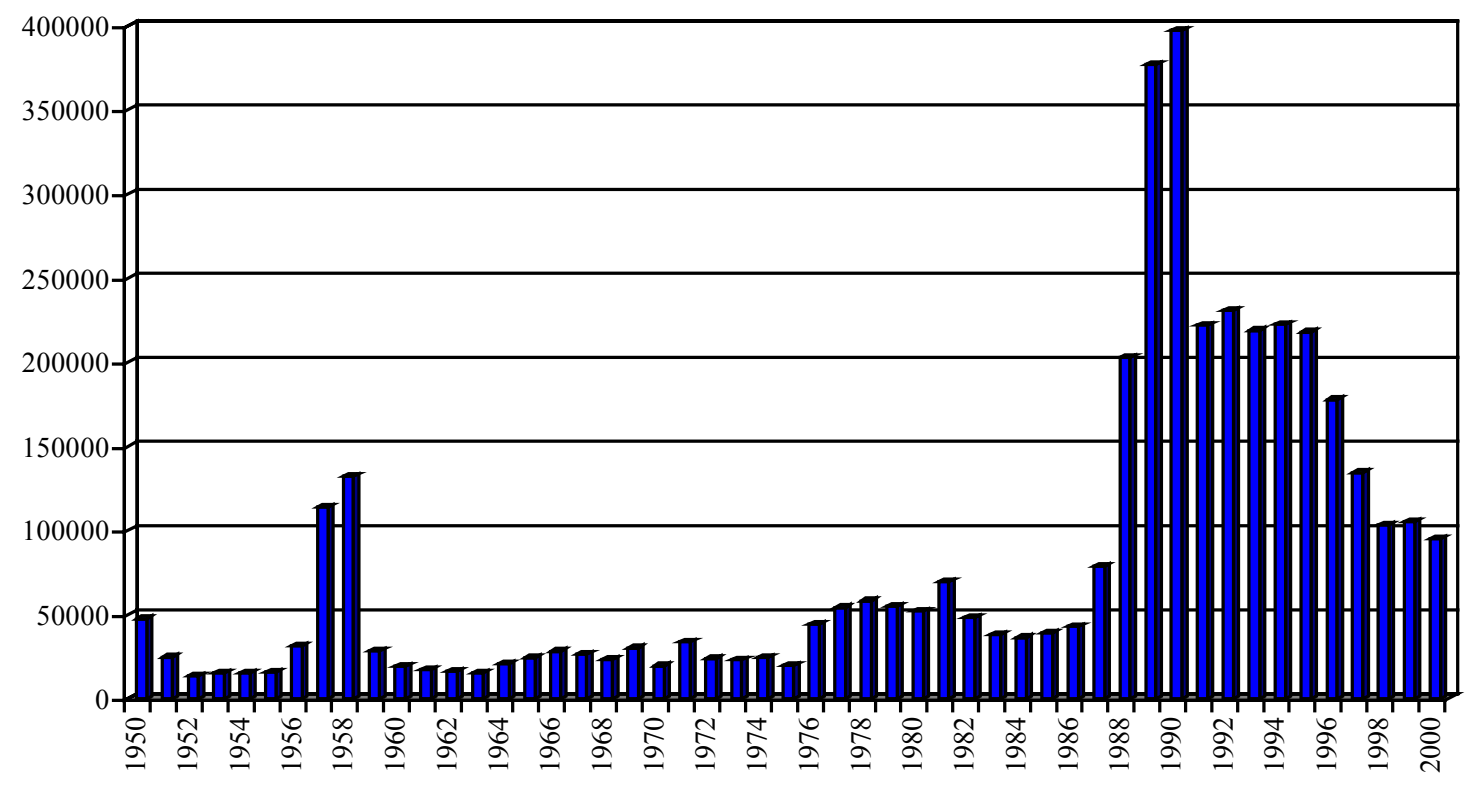

Source: Federal Ministry of the Interior

Aussiedler numbers have fluctuated widely over the last twenty years (see Figure 2). On average, only 50,000 Aussiedler per annum immigrated into the Federal Republic prior to 1989. The yearly average rose to almost 400,000 in 1989 and 1990, when mobility restrictions were abandoned and the economic collapse of Eastern Europe occurred. By the mid-1990s, these numbers stabilized to some 200,000 Spätaussiedler arrivals per year. They have decreased since then and stabilized to a comparatively low level of about 100,000 between 1998 and 2000. Three main reasons account for this decline in the Aussiedler flow. First, the screening practice has become stricter. Second, the German parliament introduced an entry quota for ethnic Germans at the end of 1992. Not more than 200,000 ethnic Germans (+/- 10\%) annually were allowed to enter Germany. In response to the decreasing numbers of Spätaussiedler applications, this quota was reduced to 100,000 in 1999. Including other legal arrangements for Spätaussiedler, the quota could well be recognized as a special de facto immigration act for one particular group of persons. Third, a qualifying language test was introduced in 1996 and is administered in the 
"home" country prior to arrival in Germany. This requirement has been one of the major factors that have reduced the immigration flow of Aussiedler.

Arrivals and departures of Ausländer or non-ethnic foreigners also fluctuated widely in recent decades. During the period 1955-1973 so-called Gastarbeiter or "guest workers" from Italy, Spain, Portugal, Greece, Yugoslavia, Maroc and Turkey were recruited by Germany as manual labour to alleviate drastic labour shortages in industry and trade. Initially recruited as temporary labour, many of them made Germany their permanent residence. The underlying reason for staying in Germany was the nature of Germany's immigration policy. After the official recruiting stop in 1973, these "guest workers" would have been denied re-entry into Germany after leaving the country. Therefore, many decided to stay "for good" and raise their families in the relative prosperity Germany offered compared to their home countries. The result was a further increase in the percentage of foreign residents.

This situation changed fundamentally after the fall of the Iron Curtain in Eastern Europe, when the influx of foreigners increased dramatically. In 1991-92 there were over 1 million net arrivals of Ausländer in Germany, mainly from Yugoslavia, Poland and Romania. Between 1993 and 1996 another 800,000 foreigners arrived. In 1997-98, Ausländer numbers receded, and the number of foreigners who actually left Germany was higher than the one of those who entered. However, in 1999, the net arrival of foreigners again amounted to over 100,000. Several ad hoc reasons account for this development. First, the Ausländer law regulating the limited rights of foreigners in Germany was tightened. Second, new restrictions on the Asylrecht (or right of asylum) within the German Grundgesetz (Basic Law) reduced the entry rights of Ausländer. ${ }^{24}$ Third, refugees of civil war in former Yugoslavia began returning to their home countries. ${ }^{25}$ Finally, improved economic conditions in eastern and central European countries reduced the number of potential immigrants.

\footnotetext{
${ }^{24}$ The policy toward asylum seekers underwent a sharp change in 1993. Refugees were no longer able to apply for asylum if they were eligible for asylum in a neighbouring country. At the same time, welfare support for asylum seekers was reduced.

${ }^{25}$ Of 345.000 civil war refugees, to date more than 300.000 have returned to their home countries.
} 
Table 3: Migration of Foreigners Into and Out of Germany 1991 to 1999

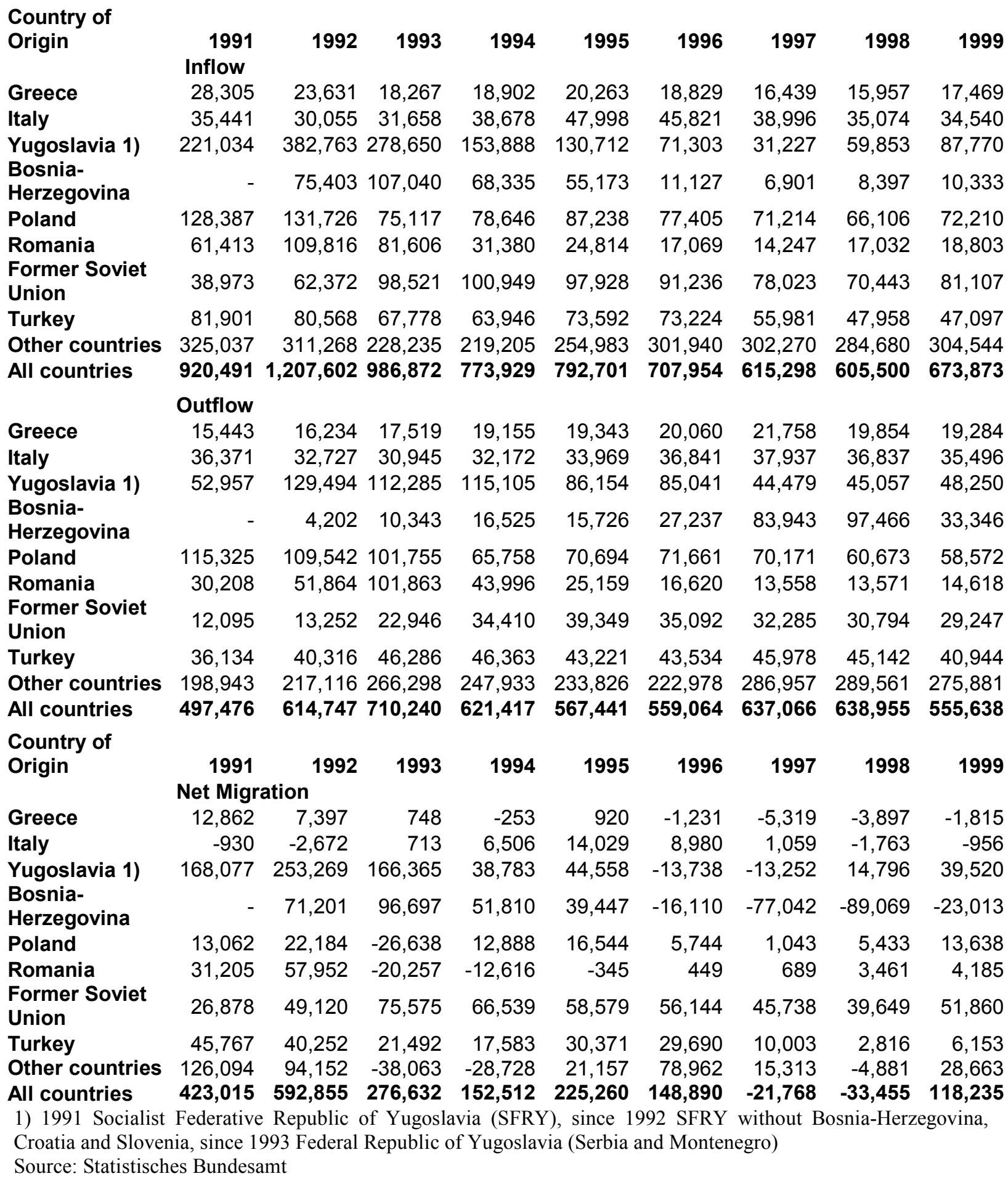


Figure 3 summarizes long-term trends in both Aussiedler and Ausländer inflows from 1951-1998.

Figure 3: Population of Aussiedler and Ausländer in Germany, 1951-1998

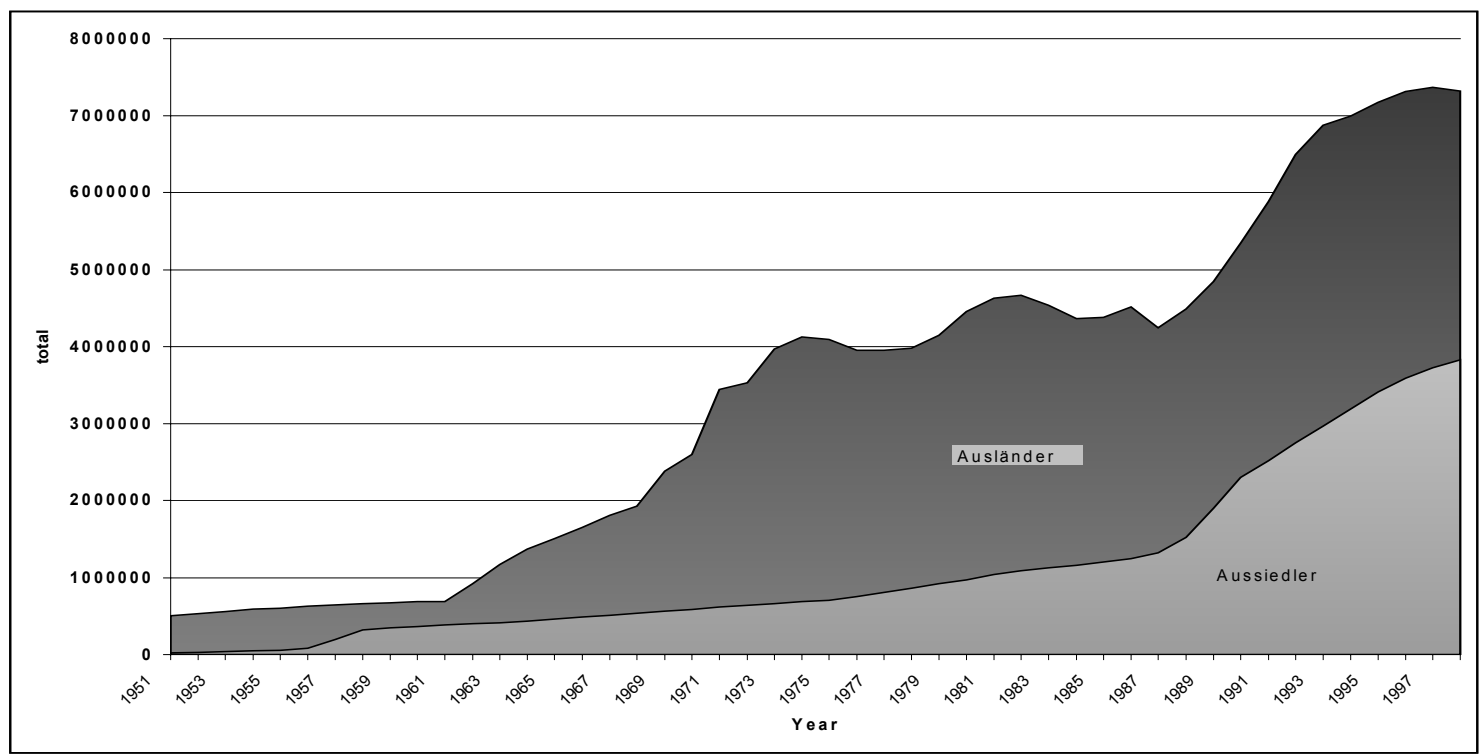

Source: Statistisches Bundesamt, Bundesanstalt für Arbeit

Almost $50 \%$ of "German" foreigners have been in the country for more than a decade, with $30 \%$ in residence for more than 20 years. As a consequence, there are now second- and third-generation families of former "guest workers" in Germany. Moreover, the original "guest workers" are loosing the majority within the group of foreigners. Today, their children, most of whom are born in Germany, and new immigrants, especially from Eastern Europe, are of growing importance. Thus, the integration of foreigners has once again become a crucial issue.

The social and labour market situation of Ausländer is to a large extent comparable to the situation of Aussiedler in Germany. The same applies to potential new foreign or ethnic German immigrants. Most ethnic Germans still living in Eastern Europe are members of the second and subsequent generations. They never lived in Germany and thus face similar "starting conditions" in their new home country as foreigners do. 
The high influx of immigrants during the last decade has resulted in considerable integration problems. To a certain extent, these problems are due to immigrants' lack of language skills and are possibly a reason for increased xenophobia. 


\section{Confirmation of German Citizenship}

\section{Naturalization of foreigners}

While the first immigration act in Germany is expected to enter into force as late as 2003, the country has a substantial legal history on rules for citizenship. The Reichs- und Staatsangehörigkeitsgesetz (RuStAG) initially regulated German citizenship status. Implemented in 1914, these statutes have undergone many changes, with crucial elements added in 2000. As of 1999, German citizenship could be obtained by birth (if one parent is German), by legitimization (for offspring of unmarried parents), or by marriage to a German citizen. Under the legal statute of the Ausländergesetz or Aliens Act ( $(86)$, claims for naturalization could be made after 15 years of residence; an application for naturalization could not be refused if certain legal conditions were met (Anspruchseinbürgerung or legal entitlement to a facilitated naturalization). For adult applicants, these naturalization conditions included: the ability to conduct business in an unconstrained manner, no criminal record, stable accommodations, and the ability to be self-sustaining (including dependants). In addition, foreign youth could file a legal citizenship claim if they had stayed in Germany for at least eight years, six of which they had to have been enrolled in a German school (Ausländergesetz, § 85).

Until January 2000, German language skills were not a prerequisite for naturalization. However, foreigners applying for expedited discretionary naturalization prior to 2000 (in most cases after ten years) were subject to a language assessment, which was only vaguely defined. According to German naturalization regulations (Einbürgerungsrichtlinien), the applicant needed a "voluntary and continual inclination and disposition" toward Germany and "especially must achieve the same proficiency in written and spoken German as is expected of others in his or her sphere of life. For older applicants, educational background and other difficulties associated with language acquisition can be taken into account, particularly when the rest of the family has sufficient German language skills and naturalization of the entire family seems desirable."26

Sufficient language knowledge according to this guideline was determined on estimation through an interview with a naturalization officer. The debate and political pressure generated by

\footnotetext{
${ }^{26}$ Unofficial translation of Einbürgerungsrichtlinien (3.1.1.).
} 
the post-1991 immigrant arrivals led to a crucial amendment of the citizenship and naturalization law in 1999. Within the new law (Staatsangehörigkeitsgesetz - StAG), in effect since January 1, 2000 , the required minimum period of residence was shortened from 15 to 8 years. More importantly, in addition to the descending principle (ius sanguinis) for citizenship, a place-ofbirth principle (ius soli) was added. Now, children of foreign parents automatically qualify for German citizenship if one parent is born in Germany or has established permanent residence status in Germany (after 8 years). The parents' foreign citizenship can initially be kept, but descendants must give up one nationality before their twenty-third birthday, which excludes permanent dual citizenship.

Since January 2000, Anspruchseinbürgerungen are already possible after 8 years of residence in Germany (Ausländergesetz, § 85-86 new). Proof of "sufficient" German language skills - beside the criterion of "loyalty to the constitution" - was added as a new prerequisite. The new law explicitly mentions insufficient language skills as a rationale for filing a legal claim to German citizenship. According to the general administrative provisions in the German citizenship and naturalization law (StAR-VwV, see Appendix B), the applicant for citizenship has to proove that he or she "is able to conduct his/her way in daily life with respect to language including usual contact with the authorities in his/her German environment. [...] Ability to communicate orally in a basic way is not sufficient."

Furthermore, the cited general administrative provisions list language certificates, school grades, university degrees and completed vocational training as acceptable proof of the required language skills, which can usually be a substitute for the special examination by the naturalization authorities. In ambiguous cases, however, it is within the discretion of the authorities to require a separate language proficiency test. Applicants can obtain the Certificate in German, which is mentioned in the general administrative provisions, from adult education centers and other institutions at their own cost.

As far as the alternative personal examination appearance of the applicant is concerned, no agreement has been reached on a uniform language assessment standard. The federal states (Bundesländer) organize these language tests in diverse ways. In some cases, the test itself is delegated to local adult education centres. These tests are 45 minutes in duration, and the fee is low. The test can be repeated, if necessary. Other federal states require personal communication 
with a naturalization officer. While some Bundesländer concentrate on oral language skills, others attach special importance to written exams, except concerning illiterate persons and children required to attend school. As a matter of fact, though, of all applicants to citizenship filing legal claims referring to the new Staatsangehörigkeitsgesetz only a minority cannot provide the required documents. Currently no reliable information is available as to the effectiveness of the language examinations. ${ }^{27}$

\section{Entry Application and Naturalization of Aussiedler}

During the Second World War, "collective naturalizations" (Sammeleinbürgerungen) were undertaken in the occupied states, granting German citizenship status to all ethnic Germans living in these regions. After the war, many ethnic Germans were subjected to discrimination, deportation, repression, and persecution. Ethnic Germans were stripped of their German citizenship status and forced to become nationals of their country of residence. This latter point gave rise to the Bundesvertriebenengesetz (BVFG). Article 116, 1 of the Federal Republic of Germany's Grundgesetz or Basic Law (see Appendix A) declares that the ethnic German population in those countries consists of "Germans without German citizenship". This special status grants ethnic Germans the same rights as other German citizens, should they decide (or be allowed) to come to Germany.

To qualify as Aussiedler, the applicant has to provide evidence of German ethnic origin, as well as proof that $\mathrm{s} / \mathrm{he}$ still identifies with German culture through the continued use of the German language and by practising German traditions. After 1996, a language test was instituted to verify the ethnic affiliation of Spätaussiedler. If the application is approved, the applicant can apply for German citizenship without the residence requirement of 15 years (since January 1, 2000, eight years) applicable to foreigners. The rationale for this reduced residence requirement for Aussiedler is their special status under German law.

The applicant must apply either in person from his/her country of residence directly to the Bundesverwaltungsamt (BVA) in Cologne or through a German consulate or embassy in the residence country. A third option open to the applicant is to apply through representatives

\footnotetext{
${ }^{27}$ Information given by the federal state of Bavaria, which requires oral and written exams, indicates a comparatively low 20 percent of failures.
} 
(usually relatives) in Germany. The processing time from application to the issuance of the Spätaussiedler certification may take up to four years. 


\section{E. Aussiedler Language Tests}

Given the large number of applicants and the ensuing debate on numbers, Germany, as noted, introduced a language test in 1996 to assess Aussiedler applicants' knowledge of German more accurately. The label 'test' is slightly misleading because it is not a test in the usual sense, but rather a hearing in which the applicant's status is assessed. The test is not repeatable because the purpose of the hearing is to assess whether the German language has been imparted to the candidate during his/her childhood (a requirement to qualify for Spätaussiedler status), not whether s/he learned German through course work. This language test is conducted locally either by employees of the BVA (in Russia and Kazakhstan) or by the German embassy or consulate. ${ }^{28}$ After the test's introduction, the $B V A$ widely publicized crucial features of the language test. The importance of passing the language test for a successful application was emphasized, as was the fact that the test was mandatory for every primary applicant.

After the application has been received, the $B V A$ issues an invitation to take the language test to either the applicant or his/her representative in Germany. A one-month interval is allowed for the letter to arrive at its destination with a second one-month interval for the applicant to register with the German embassy.

Given this seemingly inflexible application procedure, flexibility does arise in the form of alternative tests. There are two types of tests: basic and qualified. Until now, the basic test is for the primary applicant only. However, other family members can take an optional so-called "qualified" test. For the first time, the qualified test creates an incentive. It is felt that language proficiency is an important ingredient in the integration process of Aussiedler and their families into German society. If the family as a whole speaks German well (i.e., better than required under the basic test), then the whole family can take the language test. If they pass the qualified test, the application procedure will be fast-tracked. Since the average processing period of an application is four years, the incentive to take and pass the qualified test is high.

\footnotetext{
${ }^{28}$ Language tests have been conducted at the Rumanian and Polish embassies. Due to an increase in applicants from Russia and Kazachstan, the embassies by themselves were not able to cope with the volume of applications. Thus, representatives of the $B V A$ were sent there to conduct the tests. It should be noted that the results of the language tests before 1996 were not officially recorded.
} 
However, as Table 4 shows, the percentage of families passing the qualified test is not very high. This is due to the fact that more and more applicants for the Spätaussiedler status have little past exposure to German culture or language. While the share of ethnic Germans is decreasing, the share of accompanying family members is increasing steadily. Most of them lack any German language skills. The new immigration act is the first attempt to deal with this issue. It provides that all family members of potential Aussiedler first have to furnish proof of sufficient proficiency in German in their country of residence before being issued a visa. ${ }^{29}$

${ }^{29}$ Cf. Immigration Act, article 6, no. 5, documented in Appendix C. 
Table 4: Results of Language Tests for Spätaussiedler

\begin{tabular}{|c|c|c|c|c|}
\hline & Basic Test & Qualified Test & $\begin{array}{c}\text { Passed Basic } \\
\text { Test, but Failed } \\
\text { Qualified Test }\end{array}$ & Total \\
\hline \multicolumn{5}{|l|}{$\underline{1996}$} \\
\hline Tests conducted & 5,629 & 2,567 & & 8,196 \\
\hline $\begin{array}{c}\text { Passed } \\
\text { Number } \\
\text { in } \%\end{array}$ & $\begin{array}{c}3,901 \\
69.3 \\
\end{array}$ & $\begin{array}{c}1,386 \\
54.0 \\
\end{array}$ & +688 & $\begin{array}{r}\mathbf{5 , 9 7 5} \\
72.9 \\
\end{array}$ \\
\hline $\begin{array}{c}\text { Failed } \\
\text { Number } \\
\text { in } \%\end{array}$ & $\begin{array}{c}1,728 \\
30.7 \\
\end{array}$ & $\begin{array}{c}1,181 \\
46.0 \\
\end{array}$ & -688 & $\begin{array}{c}2,221 \\
27.1\end{array}$ \\
\hline \multicolumn{5}{|l|}{$\underline{1997}$} \\
\hline Tests conducted & 46,727 & 10,583 & & 57,236 \\
\hline $\begin{array}{c}\text { Passed } \\
\text { Number } \\
\text { in } \%\end{array}$ & $\begin{array}{c}29,610 \\
62.9\end{array}$ & $\begin{array}{c}4,176 \\
39.5\end{array}$ & $+2,772$ & $\begin{array}{c}36,558 \\
63.9\end{array}$ \\
\hline $\begin{array}{c}\text { Failed } \\
\text { Number } \\
\text { in } \% \\
\end{array}$ & $\begin{array}{c}17,043 \\
36.5 \\
\end{array}$ & $\begin{array}{c}6,407 \\
60.5 \\
\end{array}$ & $-2,772$ & $\begin{array}{c}21,678 \\
36.1 \\
\end{array}$ \\
\hline \multicolumn{5}{|l|}{$\underline{1998}$} \\
\hline Tests conducted & 51,607 & 7,322 & & 58,929 \\
\hline $\begin{array}{c}\text { Passed } \\
\text { Number } \\
\text { in } \% \\
\end{array}$ & $\begin{array}{c}30,064 \\
58.3 \\
\end{array}$ & $\begin{array}{c}1,888 \\
25.8 \\
\end{array}$ & $+2,088$ & $\begin{array}{c}34,040 \\
57.8\end{array}$ \\
\hline $\begin{array}{c}\text { Failed } \\
\text { Number } \\
\text { in } \% \\
\end{array}$ & $\begin{array}{c}21,543 \\
41.7 \\
\end{array}$ & $\begin{array}{c}5,434 \\
74.2 \\
\end{array}$ & $-2,088$ & $\begin{array}{c}24,889 \\
42.2\end{array}$ \\
\hline \multicolumn{5}{|l|}{ 1999 (as of 31.07.) } \\
\hline Tests conducted & 12,918 & 2,017 & & 14,935 \\
\hline $\begin{array}{c}\text { Passed } \\
\text { Number } \\
\text { in } \%\end{array}$ & $\begin{array}{c}7,141 \\
55.3\end{array}$ & $\begin{array}{l}431 \\
21.4\end{array}$ & +613 & $\begin{array}{c}8,185 \\
54.8\end{array}$ \\
\hline $\begin{array}{l}\text { Failed } \\
\text { Number } \\
\text { in } \%\end{array}$ & $\begin{array}{c}5,777 \\
44.7 \\
\end{array}$ & $\begin{array}{c}1,586 \\
78.6 \\
\end{array}$ & -613 & $\begin{array}{c}6,750 \\
45.2 \\
\end{array}$ \\
\hline
\end{tabular}

Source: Statistik Bundesverwaltungsamt Köln, Germany, as of 31.07.1999

The actual testing procedure is straightforward. Both tests are conducted orally. The questions relate to everyday life situations (household, work, leisure, etc.), not to complex political or economic events. Because applicants often speak an old German dialect, the 
applicant can choose to conduct the interview in this dialect. The examiners are specially trained in old dialects.

The aim of the test is to assess whether simple communication is possible between the examiner and the applicant. The questions and their answers are recorded on standard forms. If communication is possible, the interview is cut short and the applicant immediately passes. If communication problems arise, the interview will be transcribed word by word. At this point, the test is divided into two parts. In the first part, the interview is recorded by the examiner and the form is then signed by the examiner and the applicant. In the second part, the examiner comments on the interview and evaluates the applicant's language ability. This sheet is then signed only by the examiner and, if necessary, the interpreter. If communication is possible, even if there are faults in the grammar, syntax and language flow, the applicant is given a passing grade. If communication is impossible and if the applicant does not seem to understand many of the questions asked, the result is a failing grade.

If, however, the applicant is not able to speak coherently, but nonetheless seems to understand the questions asked, the examiner asks questions about German customs observed in the applicant's home. This part of the interview is conducted in a language that the applicant understands. If the examiner feels that German customs and traditions have been sufficiently upheld in the applicant's home to qualify under $§ 6(2)$ BVFG, s/he can pass the applicant. ${ }^{30}$

As Table 4 shows, the percentage of applicants passing the test has declined steadily since 1996. This is a result of the above-mentioned "second generation problem" and a "skimming" effect, with the more fluent ethnic Germans being processed earlier.

\section{Selection of Successful Candidates}

Depending on the results of the language test and the validity of documents, the $B V A$ will either approve or refuse the application, or conduct a further investigation. If the $B V A$ reaches a

\footnotetext{
${ }^{30}$ Because ethnic Germans were often severely disadvantaged or even persecuted in the countries they lived in, they were under pressure to assimilate to some degree. The most obvious sign of their origin would be their language, so parents often encouraged their children to speak the local language. In Poland, the use of German was actually forbidden for several decades after World War II. However, passive knowledge of the language often survived.
} 
positive decision, it must still seek permission from a Bundesland (according to $\S 28$ (2) BVFG) before it can send out the final approval.

In order to obtain this permission, the application is forwarded to the Bundesland (federal state) in question, depending on family ties and the allocation key ( $\$ 8,3$ BVFG). The federal state then conducts its own investigation and arrives at a decision independently of the $B V A$. If both agencies agree, the final approval is sent to the candidate. If the Bundesland reaches a negative decision, the application is rejected. In this case, the applicant can appeal the decision.

After receipt of the formal letter of approval (Aufnahmebescheid), the applicant uses the document to obtain a visa at the embassy. With this visa, entry into Germany is secured. After the applicant's arrival in Germany, his/her documents are again examined by the initial contact agency in Germany. If the conditions are met, the applicant (and his/her accompanying family members, if applicable) is registered, is given the option to "Germanize" his/her name, and is referred to the reception authority, Landesaufnahmestelle, in the Bundesland to which $\mathrm{s} / \mathrm{he}$ is assigned. If the documents are found to be invalid, the applicant is deported.

After arrival at the pre-determined location, the documents are once again scrutinized, and only then is the applicant finally issued the Spätaussiedler certificate. Even at this last step the application can be rejected and the issuance of the Spätaussiedler certificate refused. In this case, the applicant can appeal the decision, but may still be deported if his/her visa is revoked.

Due to the complexity of this process, it is not surprising that only a limited number of applications can be processed every year. However, the decreasing number of applications, which is due also to the implementation of the language tests, is likely to speed up the process in the future.

On the whole, the twin goals of screening and integration are often in conflict when assessing the language capability of Aussiedler. The current language test for ethnic Germans is often insufficient to ensure a functional vocabulary because outdated German spoken by many Aussiedler is permitted. Therefore, ethnic Germans and foreigners face similar communication problems in Germany, even though the two groups' admission procedures are completely different under German law. 


\section{F. Canada's Market-Based Language Tests and Instruction}

Although minimal official screening for language skills exists at the point of entry, language knowledge is nevertheless continuously assessed throughout the individual's stay in Canada. The Canadian labour market takes an active role in this informal evaluation. In fact, the individual's success in the Canadian labour market is ultimately based on his/her degree of second language acquisition. Table 5 provides an overview of Canadian immigrant language assessment from point of entry to citizenship in order to highlight the role of Canada's private sector in second language acquisition. This 3-by-3 matrix summarizes language assessment across linguistic attributes (listening, speaking, reading and writing) and by stage of integration in Canada. Upon entry as a landed immigrant, no formal language requirement is made, but language knowledge increases an applicant's chances of gaining landed immigrant status.

Table 5: Overview of Language Requirements in Different Phases of Immigrants' Residence in Canada

\begin{tabular}{|l|c|c|c|}
\hline & $\begin{array}{c}\text { Landed } \\
\text { Immigrant* }\end{array}$ & $\begin{array}{c}\text { On-the-Job } \\
\text { (various degrees) }\end{array}$ & Citizenship \\
\hline Listening/Speaking & No & Yes & No \\
\hline Reading comprehension & No & Yes & Yes \\
\hline Writing & No & Yes & No \\
\hline
\end{tabular}

* Information on language knowledge is provided through self-assessment. In most cases, the applicant is asked to a personal interview, where his/her claims are being tested orally. However, applicants have the option to forego the interview by writing the TOEFL test.

The self-regulating nature of Canada's assessment of second language acquisition is best seen in the highly qualified professions. In fact, some professions have instituted formal language tests for immigrants prior to their taking the professional qualification examinations. For example, the College of Physicians and Surgeons of British Columbia requires foreign physicians to "speak, read and write English to the satisfaction of the registrar"31 even in order to be considered for certification in Canada. In addition, a partial requirement for licensure is the "satisfactory completion of two years of accredited and approved postgraduate training [of which

\footnotetext{
${ }^{31}$ College of Physicians and Surgeons of British Columbia (1997), Section 73 (c), 1.
} 
one] of the two years must be in Canada if not a Canadian graduate." ${ }^{, 2}$ Even though the Royal College of Physicians and Surgeons of Canada does not have any formal language tests, "the postgraduate training positions do require English for acceptance to their programmes." Some even require a minimum score of $600^{33}$ on the Test of English as Foreign Language (TOEFL). ${ }^{34}$ Before an international medical graduate can become a Licentiate (L.M.C.C.), s/he must pass the examinations of the Medical Council of Canada. ${ }^{35}$ These licensure exams are conducted in English and French only, so that sufficient knowledge of English and/or French is necessary to pass the tests.

Another example of the self-regulating language mechanism operating in Canada's labour market is the language skill assessment of foreign-trained nurses. In addition to meeting all professional requirements, the Registered Nurses Association of British Columbia requires all nurses, whose first language is not English, to provide evidence of fluency in English by passing both the TOEFL test with a minimum score of 550 as well as the Test of Spoken English (TSE) with a score of at least 50 . Other provinces have similar regulations.

In order to practice pharmacy in Ontario, pharmacists "must have a Certificate of Registration (licence) as a Pharmacist from the Ontario College of Pharmacists." The Ontario College of Pharmacists further requires foreign-trained pharmacists to demonstrate that they can understand, speak, and write either English or French. This can be proven by passing the TSE (50 or higher), TOEFL (580 or higher), and the Test of Written English (TWE - 5 or higher) or any other recognized test, like the CanTEST (at least 5 on each section - listening, reading, writing, speaking). For French language proficiency, the requirements are either the CanTEST (same minimum scores as English) or the Test of Business French ( 7 on oral, 2 on writing). Furthermore, applicants for the Certificate must complete "48 weeks of in-service training" and "pass the Pharmacy Examination Board of Canada (PEBC) Qualifying Examination and the

\footnotetext{
${ }^{32}$ Ibid.

${ }^{33}$ The scores quoted here apply to the paper-based TOEFL. A concordance table for comparison with the scores of the computer-based TOEFL is provided for in the TOEFL-CBT-Bulletin (available at www.toefl.org).

${ }^{34}$ Dr. D. H. Blackman, Deputy Registrar, College of Physicians and Surgeons of British Columbia, personal correspondence by Don DeVoretz, July 22, 1999.

${ }^{35}$ Being a Licentiate is a prerequisite for admission to the postgraduate training programme.
} 
Ontario College of Pharmacists Jurisprudence Examination., ${ }^{, 36}$ Both of these examinations are conducted in either English or French only.

In non-health related occupations, similar language requirements exist. For example, in order to practise law in Canada, the National Committee on Accreditation examines foreigntrained lawyers' credentials and determines what further upgrading courses must be taken to obtain the Certificate of Qualification, a prerequisite for admission as a barrister or solicitor.

The Certificate testifies that the applicant has education and training equivalent to graduates from an approved Canadian law school. After obtaining the Certificate of Qualification, the applicant may proceed to a bar admission and articling program on the same basis as a graduate from an approved Canadian law school. ${ }^{37}$

Depending on the language of instruction of the applicant's law program at home, the committee may ask for evidence of demonstrated competence in English. Furthermore, the universities where the upgrades are taken always require the TOEFL test as proof of English proficiency.

Other examples of prior language assessment abound. The Association of Professional Engineers and Geoscientists of British Columbia requires that all engineers pass the Professional Practice Examination prior to practising as professional engineers. This test is conducted only in English; therefore, foreign-trained engineers must possess a sufficient knowledge of English to pass the exam. Similar linguistic examination requirements exist in other Canadian provinces.

Licensing as a physiotherapist in Ontario requires, apart from professional prerequisites, fluency in either English or French. Minimum requirements are a TOEFL score of at least 585, plus a TSE score of at least 45, or a minimum score of 85 on the Michigan English Language Assessment Battery (MELAB). Alternatively, an average score of at least 3 on the CanTEST (English or French) or at least 7 on the International Language Testing System (IELTS) can be submitted as proof of adequate language proficiency.

Finally, the College of Dieticians in Ontario requires all foreign-trained dieticians to prove English or French language fluency. The recognized testing instruments are the TOEFL test (550 or higher) and the TSE ( 5 or higher).

\footnotetext{
${ }^{36}$ The above was taken from the 1997 Occupational Fact Sheet for Foreign Trained Pharmacists, http://www.ocpharma.com/Registration/putprov.asp
} 
Even in professions that do not require formal education, language proficiency is often tested. For example, to be licensed as a taxi driver in British Columbia, one does not only have to pass the TaxiHost Basic Geography Test and TaxiHost courses, possess a satisfactory driving record with no serious criminal record, but also has to demonstrate "an ability to copy printed information in English onto a form, present valid evidence of completing Grade 8 English or higher from any English-language school, OR pass the TaxiHost English Proficiency Test ${ }^{\text {"38 }}$ with at least 78 percent on the oral communication, 71 percent on the pronunciation, and 67 percent on the reading portion of the test. The TaxiHost English Proficiency Test was instituted to provide a fair and objective test to determine the applicants' English skills regardless of their country of origin. It was developed by the Vancouver Community College for TaxiHost to ensure that taxi drivers possess the oral, listening, and speaking skills necessary to work proficiently in their profession.

In sum, even though the Canadian government does not mandate knowledge of either official language to gain entry into Canada, to stay in Canada, or for naturalization, the Canadian labour market imposes a rigorous language standard for many immigrants. This leads to the paradox that even though immigrant admission can be gained by the possession of skills and without language knowledge, an immigrant still needs extensive language skills to practise his or her occupation after admission.

The myriad of language tests and the varying levels of second language competency required by individual professions has led to a debate over language standards. Canada has thus begun to develop a "benchmark" standard for levels of second language acquisition. This uniform evaluation system is an attempt to better inform the immigrant of his/her required language standard in his/her profession.

\footnotetext{
${ }^{37}$ National Committee on Accreditation, Evaluation of Legal Credentials of Accreditation, http://www.flsc.ca/english/cm-nca.htm

${ }^{38}$ TaxiHost Centre, New Driver Application Procedures, Justice Institute of B.C., last revised January 4, $1999,1$.
} 


\section{G. Canada's Language Benchmarks}

Given the plethora of Canadian immigrants with inadequate language skills, the private sector has responded with a variety of English (and French) as a Second Language (ESL/FSL) teaching institutions. However, most private institutions do not follow a national standard. ${ }^{39}$ This makes it harder for prospective employers to compare graduates of different programmes and to assess their actual levels of knowledge realistically. ${ }^{40}$ Furthermore, in most ESL courses, "language assessment may be too limited in scope [...] to reflect the range and quality of language uses that are actually fundamental to participation in Canadian society." 41 Finally, "while there is a general trend in education towards accountability and outcomes-based curricula, ESL programs lack information and empirical validation that would provide evidence on the standards of learning outcomes achieved." 42 Keeping this observation in mind, the "development of the CLBA (Canadian Language Benchmarks Assessment) can be seen as a response to the limitations of adult ESL instruction and assessment." ${ }^{43}$ The history of the development of Canadian Language Benchmarks is outlined below.

In 1991, the predecessor ministry to CIC stated in its annual report to Parliament its objective of improving language training for adult newcomers to Canada, including the improvement of language assessment methods. To achieve this goal, in 1993 the National Working Group on Language Benchmarks was established to oversee the design, field-testing and revision of a set of language benchmarks that would describe "a person's ability to use the English language to accomplish a set of tasks." 44 The National Working Group on Language Benchmarks included about 20 instructors, administrators and participants (learners) from across the country. The result of this combined effort was the development of a document called Canadian Language Benchmarks: English as a Second Language for Adults in 1995.

\footnotetext{
${ }^{39}$ Facilities include schools, colleges, community centres, universities, factories, offices, hotels, church basements, libraries, etc. Classes are full-time or part-time, and learners are very diverse in their cultural and educational backgrounds.

${ }^{40} \mathrm{CIC}$ (1996a), 1.

${ }^{41}$ Cumming, quoted in Norton and Stewart (n. d.), 3.

${ }^{42}$ Ibid.

${ }^{43}$ Ibid.
} 
The Canadian Language Benchmarks are "a set of twelve language proficiency standards, which can be used to describe the language skills of ESL students in three areas: speaking and listening, reading and writing." ${ }^{\text {45 }}$ Each benchmark gives a description of competencies that a learner at that level should demonstrate. Each area outlines four competencies that are consistent across benchmarks (see Table 6).

Table 6: General Content of Canadian Language Benchmarks
A. following and giving instructions
Listening/Speaking
B. social interaction
C. exchanging information
D. suasion (getting things done)
A. reading instructions
Reading
B. reading formatted texts
C. reading unformatted texts
D. reading informational texts - analysis and information
A. information - copying, reproducing
Writing
B. formatted text - filling out/constructing
C. unformatted text describing, conveying messages
D. expressing ideas - analysis and evaluation, persuasion

Source: Canadian Language Benchmarks, Introduction and p.2. http://language.ca/clb/intro.html

After completion of this document, CIC contracted a Board of Education in Ontario to develop assessment instruments consistent with the benchmark document. The project mandate was to develop:

- tasks that are benchmark compatible;

- tasks that can place learners on a continuum;

- tasks that are free from racial and cultural bias;

- tasks that are realistic and fair;

- separate instruments for listening/speaking; reading; and writing;

- instruments for both placement and assessment of outcomes;

- assessment instruments that can be administered and scored in an efficient, reliable, and costefficient way;

- assessment instruments that are accountable to the field of adult learning and teaching. ${ }^{46}$

\footnotetext{
${ }^{44}$ CIC (1996a), 1.

${ }^{45}$ CIC (1996b).

${ }^{46}$ Norton/Stewart (n. d.), 4.
} 
The resulting Canadian Language Benchmarks Assessment (CLBA) is a task-based test designed to "place adult language learners across the country in instructional programs appropriate for their level of proficiency in English and to assess learner progress within these programs." ${ }^{47}$ Test instruments were developed to place learners on benchmarks 1 to $8 .{ }^{48} \mathrm{~A}$ thorough description of the Canadian Language Benchmarks can be found on the Internet under http://language.ca/clb.

ESL classes for children and teenagers are universal in Canada's school system. Furthermore, through interaction with other children immigrant children learn the dominant language spoken in their area - be it English or French - very quickly. This is not necessarily the case for adult immigrants. To facilitate adult immigrant social, economic, and cultural integration into Canada, CIC implemented a Language Instruction for Newcomers to Canada (LINC) program. ${ }^{49}$ LINC is provided by contracted service providers throughout the country. Service providers can be businesses, non-profit groups, non-governmental organizations (NGOs), community groups, educational institutions, individuals, or provincial, territorial or municipal governments.

To be eligible for LINC classes, the participant must be over 19, a permanent resident or a successful applicant for residency in Canada. A distinguishing feature of the LINC program from earlier government-sponsored language programs is that the individual applying for language training does not have to be in the labour market to be eligible for training. Before LINC, three main government-funded programs existed: the Language Training Program funded by the Canada Employment and Immigration Commission (CEIC), language instruction programs funded by the Secretary of State (funding for these programs was terminated in 1989 federal budget), and the CEIC-funded Settlement Language Training Program (SLTP), a program designed to address the language needs of immigrants not destined for the labour force.

The Language Training Program was aimed only at labour force participants. To be eligible, individuals had to demonstrate that English or French language skills were essential to their employment. The program funded by the Secretary of State was aimed at preparing

\footnotetext{
${ }^{47}$ Ibid., 2.

${ }^{48}$ Test for Benchmarks 9 to 12 are planned.

${ }^{49}$ LINC is the equivalent of ELSA (English Language Service for Adults) in the province of British Columbia.
} 
immigrants for Canadian citizenship. It was taught in the total immersion approach (English or French only) by unilingual instructors. This mode of instruction tended to make learners uncomfortable, in particular those with low literacy skills, and impeded learning. Furthermore, allegations were raised that the program was culturally insensitive and did not deal adequately with everyday situations.

The main objective of the current LINC program is to teach basic English or French language skills to adult immigrants as early as possible to facilitate integration. Language training is provided for up to three years. It is hoped that this time frame will allow the learner to meet family, employment, and other obligations that require knowledge of an official language. In order to insure access to the LINC programs, students are allowed to continue to receive public assistance, child minding and support with transportation costs to insure class attendance.

LINC courses employ uniform national training standards and consist of three components. First, the client's current language skill level is assessed by an individual using the benchmarks (CLBA) discussed above. The assessor then recommends the language training provider that best suits the client's needs. However, this recommendation is not binding. When service providers apply for funding to CIC, they are required to inform CIC about all aspects of their operation, including related services available to the clients, like childcare, wheelchair accessibility, etc.

The second component is the language training itself. To ensure a uniform quality of language training nationally, learners' progress should be measured using the noted benchmarks (CLBA). LINC providers must be qualified to teach even learners assessed at Stage 1 of the CLB.

The third component of LINC programs is "to improve and assist with the delivery of both language training and assessment within the LINC Program."50 This task requires the examination of the linguistic training needs of local immigrant groups and the evaluation of the effectiveness of the LINC programs with recommendations on how to improve deficiencies.

\footnotetext{
${ }^{50}$ CIC (1997), 5.
} 


\section{H. German Language Training}

Unlike Canada's training sector, the German language instruction system has been characterized by a strong role of the government. The German government funds language-training courses for both Aussiedler and Ausländer (see Appendix D for a synopsis). The goal of these courses is to facilitate economic and labour market integration in order to improve social contacts, and to increase political and cultural participation. Funding for the two entry groups is provided by different agencies. Language training for Spätaussiedler in Germany is funded by the Federal Ministry for Family Affairs, Senior Citizens, Women and Youth (Bundesministerium für Familie, Senioren, Frauen und Jugend - BMFSFJ), the Federal Ministry of Labour and Social Affairs (Bundesministerium für Arbeit und Sozialordnung - BMA), and the Federal Ministry of Education and Research (Bundesministerium für Bildung und Forschung - BMBF). Furthermore, potential Aussiedler are given the opportunity to refresh or improve their German language proficiency while still residing in the former Soviet Union and Kazakhstan through language courses funded by the Foreign Office (Auswärtiges Amt - AA) and the Federal Ministry of the Interior (Bundesministerium des Innern - BMI).

Government-funded language training for Ausländer, on the other hand, is provided only in Germany and is funded by the Federal Ministry of Labour and Social Affairs (Bundesministerium für Arbeit und Sozialordnung - BMA). Funding for both Ausländer and Aussiedler language training recently amounted to $\mathrm{DM}^{51}$ 340-350 million (ca. \$245-253 million Cdn.). More than 90 percent of this funding is provided for language courses in Germany, the remainder for language training in Aussiedler residence countries. Federal budgeting calculates with about DM 320 million (ca. €165 million/ca. \$230 million Cdn.) for 2001 as well as 2002. The following section gives a brief overview of the services provided and the perceived effectiveness of these programs.

\footnotetext{
${ }^{51}$ Data compared over time are presented in DM instead of Euro (=1,95583 DM).
} 


\section{Aussiedler Language Training}

In 2000, the federal government spent a total of about DM 310 million (ca. \$224 million Cdn.) on language-training programs for Aussiedler. Several different funding schemes exist, which are outlined below.

\section{a) Language Training in the Countries of Residence}

Language training offered by the German government to residents in the former Soviet Union and Kazakhstan is primarily geared to inducing ethnic Germans to stay there. Furthermore, it is intended to strengthen the German language in these regions by allowing interested nationals of these countries to participate in German language courses. This training is meant to strengthen intercultural exchanges and improve acceptance of the remaining ethnic Germans in the former Soviet Union and Kazakhstan. For those ethnic Germans who still decide to migrate to Germany, the language courses are a means of refreshing and/or improving their German language skills, thereby facilitating integration in Germany. It is estimated that currently about 1 million ethnic Germans and their relatives live in the former Soviet Union and about 300,000 in Kazakhstan. ${ }^{52}$

The Auswärtige Amt (AA) sponsors several German language courses for Aussiedler. The three most prominent are courses provided by the German embassy in Kazakhstan, courses and work groups of the Society for German Culture Abroad (Verein für das Deutschtum im Ausland - VDA), as well as a series of other more indirect measures. The goal of these courses, according to the Council of Germans in Kazakhstan, is to provide a linguistic basis for those who are considering emigration to Germany and aid in the decision-making of those who are still undecided. The courses are free of charge to participants, who may take up to three courses of 160 hours each. At the end of each course, a test is administered consisting of written and oral parts. In 1998, the $A A$ and the $B M I$ spent about DM 2.1 million (ca. $\$ 1.52$ million Cdn.) on these courses, funding about 750 courses with some 15,000 participants.

\footnotetext{
${ }^{52}$ Dormann et al. (1998), 26.
} 
German courses in Kazakhstan and the former Soviet Union are also offered through the Verein für das Deutschtum im Ausland (VDA). The VDA has offered "integrated language courses" in Kazakhstan and the former Soviet Union since 1993. In these courses, participants not only attend structured language classes but also learn and improve their German through community activities like cooking, dancing, and choir practice. The main goal of these activities is to maintain the German language and culture in the former Soviet Union and Kazakhstan. Apart from ethnic Germans, nationals of the regions can also participate, and indeed the latter make up about $50 \%$ of all participants. Up to four consecutive language courses ( $4 \times 40$ hours) may be taken. The "work groups" usually entail 32 hours a month, and a language test is administered here as well.

Language courses in the former Soviet Union and Kazakhstan are often hindered by a shortage of teaching materials, facilities, and qualified teachers. Therefore, the $A A$ provides funding and training opportunities for teachers to address these shortages.

The Bundesministerium des Innern (BMI) funds language training for family members of the ethnic German minorities in the former Soviet Union. The underlying goal is to provide an incentive to stay in the region by strengthening German identity and unity between ethnic Germans of the region. Language courses are an important part of the programs offered. Furthermore, the BMI establishes meeting centres (Begegnungsstätten) where ethnic Germans and interested nationals can meet and contribute to a German-Russian cultural and linguistic exchange. These measures, called Breitenarbeit, have attracted more than 200,000 persons since their inception in 1996. The language courses are free of charge and generally accessible to everyone as long as a sizeable fraction of the participants consists of ethnic Germans. Up to 1999, the courses comprised 80 hours of instruction spread over three months, with a planned expansion to 160 hours. In contrast to the courses discussed previously, the language courses of the Breitenarbeit do not require a language test at the end of the course. Rather, a certificate of participation is issued. Funding in this field amounted to about DM 16 million (\$11.6 million Cdn.) in 1999.

In sum, even though the scope of language-training programs is extensive, no information exists on its effectiveness. One reason is that language training in the sending regions is intended 
to keep ethnic Germans from migrating. However, there is also no information on whether this language training aids those ethnic Germans who do apply for Spätaussiedler status.

\section{b) Language Training in Germany}

As mentioned earlier, language training for Aussiedler in Germany is funded by several different federal ministries: the Bundesministerium für Arbeit und Sozialordnung (BMA), the Bundesministerium für Familie, Senioren, Frauen und Jugend (BMFSFJ), and the Bundesministerium für Bildung und Forschung (BMBF). They are better structured, and conditions are more stringent than in language courses conducted in the sending regions.

Language training for more mature Aussiedler is provided by the Bundesministerium für Arbeit und Sozialordnung (BMA) through the Federal Employment Service (Bundesanstalt für Arbeit $-B A$ ) in their regional offices. These courses are geared to meeting the needs of the local labour market. The courses are fully funded for six months, including transportation and childcare costs up to a maximum of DM 120.- (ca. \$87.- Cdn.). Table 7 reports enrolment relative to arrivals for the 1991-97 period. The percentage of arriving Spätaussiedler who took part in language courses remained relatively steady (around 50\%), which indicates a continued government commitment to this program.

Table 7: Entries of Spätaussiedler in German Language Courses 1991-1997

\begin{tabular}{|l|c|c|c|}
\hline Year & $\begin{array}{c}\text { Arriving } \\
\text { Spätaussiedler }\end{array}$ & Entries & Percentage \\
\hline 1991 & 221,995 & 118,733 & $53.5 \%$ \\
\hline 1992 & 230,565 & 109,359 & $47.4 \%$ \\
\hline 1993 & 218,888 & 121,900 & $55.7 \%$ \\
\hline 1994 & 222,591 & 120,139 & $54.0 \%$ \\
\hline 1995 & 217,898 & 107,478 & $49.3 \%$ \\
\hline 1996 & 177,751 & 89,774 & $50.5 \%$ \\
\hline 1997 & 134,419 & 77,515 & $57.7 \%$ \\
\hline $\mathbf{1 9 9 1 - 1 9 9 7}$ & $\mathbf{1 , 4 2 4 , 1 0 7}$ & $\mathbf{7 4 4 , 8 9 8}$ & $\mathbf{5 2 . 3} \%$ \\
\hline
\end{tabular}

Source: Social Consult, 1998

The language courses sponsored by the $B M A$ are full-time and require attendance 5 days a week for 35 hours per week. The standards of these courses are maintained by using qualified 
second-language instructors, prior assessment and regular monitoring of progress through tests, midterms, and final exams. A participant has the opportunity to leave the course early, especially for the purpose of taking up work, if s/he has demonstrated an adequate knowledge of German. To ensure a minimum standard in the courses, service providers co-operate closely with the federal states' ministries for education regarding the curriculum and use of appropriate teaching aids. Lately, government funding through the BMA stabilized at DM 240-250 million (\$173-181 million Cdn.), resulting in a minor per capita increase in expenditures as ethnic German numbers decreased.

The Bundesministerium für Familie, Senioren, Frauen und Jugend (BMFSFJ) provides language training to integrate young Spätaussiedler into German society. Funding for this purpose is provided by the so-called "Garantiefonds", a guaranteed fund. The Garantiefonds is broken down into two components: High School and Occupational Sectors (Schul- und Berufsbildungsbereich $-S B$ ), and the University Sector (Hochschulbereich $-H$ ).

Language courses under GF-SB or Garantiefonds Schul-und Berufsbildungsbereich are specifically designed for young Spätaussiedler as well as young foreigners (under 27 years of age) with or without a high school degree, whose knowledge of German is deemed insufficient to pursue further education. The goal of these language courses is to provide sufficient language training to enable these young people to pursue further educational or occupational training, or to achieve a German high school diploma. Different language courses are offered, some of which are vocationally oriented, in combination with school teaching or boarding school accommodation. Depending on the student's future educational aspirations, course duration ranges from 10 to 12 months, 40 hours per week. Student's progress is monitored through midterm and final exams. The funding for tuition ranges from DM 630 (ca. $\$ 455 \mathrm{Cdn}$.) to DM 820 (ca. $\$ 592$ Cdn.) per month. Furthermore, in extreme cases, tutoring or boarding school may be funded if it is deemed necessary to the successful social integration of the youth. The maximum duration of funding for any individual is 30 months with a cessation in funding 60 months after arrival in Germany. In 1997, 71,886 individuals were sponsored under GF-SB, 96 percent of which were Aussiedler. Government funding for language training in this field amounted to about DM 45 million (\$32.5 million Cdn.) in 2000. 
Language training for young Spätaussiedler (under 30 years of age) who want to attend University is provided by the Garantiefonds Hochschulbereich $(G F-H)$. The goal of these language courses under this scheme is to enable the participant to obtain university qualification. The duration of this course generally is 6 months, 32 hours per week. Before entering the course, participants are tested for their existing competency in German. Progress is continually assessed through midterms, assignments, and a final exam, which can only be repeated once. Course contents reflect the socio-cultural environment in order to facilitate active language proficiency. Due to the "integration character" of the program, funding ceases 60 months after arrival and 30 months after the start of the program. In addition to tuition and schoolbooks and equipment, $G F$ $H$ funding includes transportation, and in extreme cases housing and living expenses if the student cannot live with his/her parents for the duration of the program. In 2000, DM 23 million (\$16.6 million Cdn.) were spent on $G F-H$ language courses for about 4,000 participants, 90 percent of whom were Aussiedler.

The $B M B F$ funds a program called the Akademikerprogramm (AKP). It was established in 1985 to support Spätaussiedler in academia concerning re-entry into their profession. The goal of the program is to make up for lack of knowledge of participants due to system-specific differences in education and profession. Eligible candidates for the AKP are Spätaussiedler and Kontingentflüchtlinge between ages of 30 and 50 who have completed a university degree or equivalent education in their home country that is not recognized in its current form. The $A K P$ provides an opportunity to learn German, English, or occupation-specific German, study at a German university, and participate in professional upgrades. The courses are offered full-time (35 hours per week) for three months. Funding under this program is not automatic - Aussiedler must apply for funding within one year after arrival to Germany. If successful, funding covers the costs of the linguistic (and occupational) training as well as living expenses and possibly medical coverage for the duration of the program. In recent years, government funding with regard to the $A K P$ reached an average of approximately DM 10 million (\$7.2 million Cdn.), with less than 10 percent actually spent on language training itself.

\section{Effectiveness of Spätaussiedler Language Training}

In 1998, Social Consult $\mathrm{GmbH}$ conducted an extensive survey commissioned by the Bundesministerium für Familie, Senioren, Frauen und Jugend (BMFSFJ) to evaluate the 
effectiveness of language training courses for Spätaussiedler - how the different programs are translated from theory into practice, how they are interlocked, and which aspects of the programs could be improved. The following is a short overview of the survey results for the different programs.

The survey examined 378 service providers with a total of 14,032 program participants. Of these, $82.3 \%$ are Aussiedler (including family members), $13.4 \%$ are quota refugees, and 3.9\% are persons having been granted asylum. A high percentage of participants are 28 years of age or younger (23.4\%). As Table 8 shows, a large majority of participants entered language courses soon after their arrival, $83.7 \%$ within the first six months.

Table 8: Space of Time Between Arrival and Entry into Language Courses

\begin{tabular}{|l|c|c|}
\hline & \multicolumn{2}{|c|}{ Participants } \\
\hline Up to 1 month & Absolute & In \% \\
\hline $\mathbf{1}$ to 6 months & 2,927 & 20.9 \\
\hline 6 to 12 months & 8,819 & 62.8 \\
\hline $\mathbf{1}$ to 2 years & 1,397 & 10.0 \\
\hline More than 2 years & 229 & 1.6 \\
\hline No response & 130 & 0.9 \\
\hline
\end{tabular}

Source: Social Consult Survey, 1998

This early entry pattern fosters integration and demonstrates the strong motivation of the students to learn German as soon as possible.

About 85 percent of service providers evaluate their participants' existing language skills prior to entry. Of these service providers, about 80 percent have designed testing instruments. The multitude of evaluation tests precludes a common standard and hinders comparisons between the outcomes of different courses offered. There is a need for service providers to use standardized tests to evaluate these outcomes. According to the survey, service providers listed the following as their most important goals for the BMA-sponsored language courses: 
1. Development of Communication Skills

2. Reading/Writing Skills

3. Independent Learning

4. Knowledge of German School System/Occupational System

$11.1 \%$

5. Development of Occupation/Specific Communication Skills

Almost 93 percent of service providers determine the successful completion of the course through a final exam. The pass rates are fairly high, almost 85 percent. However, no uniform final exam exists, so that direct comparisons are impossible. Furthermore, no information on the degree of difficulty of the tests is available.

About 5.5 percent (767 participants) had already taken part in a German language course in their country of origin. Of these, 57 percent performed better in the BMA-sponsored language courses than the remaining participants. This leads to the belief that the completion of language courses prior to arrival in Germany is beneficial. The very small sample of 767 , however, does not allow any final conclusion.

According to the perceptions of the surveyed service providers, most participants start the programs with a high level of motivation. As a general result of this high motivation, the effectiveness of the language courses in aiding the economic and social integration of Spätaussiedler is judged to be (very) high by most service providers (65.8\%). A possible area of improvement mentioned by service providers is the duration of the language courses. Most service providers $(77.3 \%)$ felt that increasing the duration of language courses beyond the current six months would improve their quality. ${ }^{53}$

An assessment of the Aussiedler language training as provided by the BMFSFJ is found in Table 9. This survey examined 114 service providers with a total of 5,166 program participants. Of these participants, 89.3 percent are Spätaussiedler (including family members), 5.3 percent are quota refugees, and 1.7 percent are persons who have been granted asylum. The rate of participation is relatively low: Only $44.2 \%$ began language training within six months after their arrival in Germany. However, about 75 percent of participants entered within the first

\footnotetext{
${ }^{53}$ It should be mentioned, however, that service providers would have a personal economic incentive for increasing the duration of language courses, thereby increasing the amount of funding received.
} 
year of arrival. The remaining 25 percent began language training only a year after their arrival or even later, which is a cause for concern since it delays the integration process particularly for young Spätaussiedler.

Table 9: Space of time between Arrival and Entry into GF$S B$ Language Courses

\begin{tabular}{|l|c|c|}
\hline & \multicolumn{2}{|c|}{ Participants } \\
\hline Up to 1 month & Absolute & In \% \\
\hline 1 to 6 months & 282 & 5.5 \\
\hline 6 to 12 months & 1,998 & 38.7 \\
\hline $\mathbf{1}$ to 2 years & 1,629 & 31.5 \\
\hline More than 2 years & 1,034 & 20.0 \\
\hline No response & 156 & 3.0 \\
\hline
\end{tabular}

Source: Social Consult Survey, 1998

According to the survey, service providers listed reading/writing skills as their most important goal for the GF-SB language courses, followed by the development of communication skills and independent learning. Final examination scores as reported by the service providers indicate high pass rates of almost 82 percent in the intensive language courses, and 88 percent in the occupational language courses. Service providers also reported that about 40 percent of the participants start the programs with a high level of motivation as a result of their desire to improve their labour market prospects. However, as noted above, the level of German language skills possessed by Spätaussiedler upon arrival has generally decreased over past years.

As a general result, the effectiveness of the language courses in aiding the economic and social integration of Aussiedler is judged to be high by most service providers (70\%). Possible areas of improvement mentioned by service providers are more individualized and intensified programs and smaller minimum class sizes. In addition, more co-operation between the different regional integration agencies is desired to facilitate a fine-tuning of target activities. 
The third survey reported covers all 12 service providers offering Garantiefonds Hochschulbereich $(G F-H)$ courses with a total of 1,547 program participants, 80.9 percent of whom are Spätaussiedler (including family members), 15.8 percent quota refugees, and 3.3 percent asylum seekers. About 72 percent of the participants enrol in the courses within twelve months of arrival.

Entrance exams to evaluate the participants' existing language skills are used to place the participants in one of three course levels with increasing levels of difficulty. Almost 30 percent of the participants are placed in level 2 or higher, indicating that the general level of pre-existing language knowledge is fairly high.

According to the survey, service providers listed reading/writing skills as their most important goal for the $G F-H$ language courses (50\%), followed by knowledge of German culture, politics, and economy. Lower goals were skill development for independent learning and knowledge of the German university system.

All service providers require completion of homework assignments and midterms and determine the successful completion of the course through a final exam. Pass rates are fairly high, about 77 percent pass the final exam on their first attempt. However, about 15 percent have to repeat a midterm or final exam and almost 29 percent drop the course after failing a test. The attrition rate increases with the degree of course difficulty.

Service providers judge the motivation of Spätaussiedler (73\%) as high. Thus, the effectiveness of the language courses in aiding the economic and social integration of Aussiedler is judged to be (very) high by most service providers (over $80 \%$ ). Possible areas of improvement mentioned by service providers are longer duration of courses and smaller minimum class sizes.

Policy-makers have begun aiming at arranging for better language acquisition for ethnic Germans before entry into Germany. As already mentioned, it is planned - within the framework of the immigration act - to require family members to furnish proof of proficiency in German. Moreover, all Aussiedler are to be entitled to free attendance of "integration courses" after entering Germany, which are intended for all immigrants. This provision will replace the current language program for Aussiedler in Germany. Despite the doubtful practicability of a combination of language courses for a very heterogeneous group of immigrants, these efforts can 
be taken as further evidence of an increasing awareness towards language as a vital aspect of integration policy.

\section{Ausländer Language Training}

Language training for Ausländer who live in Germany is overseen by an agency called the Sprachverband Deutsch für ausländische Arbeitnehmer e. V. It was founded by the Federal Ministry of Labour and Social Affairs (BMA) in 1974 and is completely funded by the $B M A$. In 1997, DM 24.95 million (ca. \$18.02 million Cdn.) was spent on language training for Ausländer. Since then, funding has risen to DM 32 million (\$23.1 million Cdn.) in 1999 and DM 34 million in 2000 (\$24.6 million Cdn.). On average, 68,000 individuals participated in the language courses in recent years, two thirds of them being women. The goal of these language courses is the social and economic integration of Ausländer into German society by means of task-oriented language training simulating real-life situations. The Sprachverband developed guidelines for content and quality, which are binding for service providers. In contrast to language courses for Spätaussiedler, who are generally fully funded, service providers of language courses for Ausländer can charge tuition (up to DM 2 per class hour) for each participant.

To be eligible for language courses funded by the Sprachverband, foreign workers and their families must be citizens of the European Union (EU) or of one of the former recruiting countries. ${ }^{54}$ Spätaussiedler, refugees, and persons seeking asylum as well as foreign youths under the age of 15 are not eligible for these courses.

Four main types of language courses are offered, their main difference being the number of course hours. They range from basic language courses to intensive language training.

a. Basic language courses are geared towards participants who cannot partake in classes more than three days a week (no more than 9 hours per week). They consist of a set four consecutive courses (60-80 hours) for a total of 320 hours.

b. Courses for illiterate Ausländer are geared towards foreigners who do not possess sufficient reading and/or writing skills to participate in a normal language course. These courses

\footnotetext{
${ }^{54}$ Turkey, Yugoslavia, Morocco, Tunisia, South Korea, and the Philippines or one of the recruiting countries of former East Germany: Angola, Mozambique, and Vietnam.
} 
are designed to first teach the participants how to read and write (this can be done in their mother tongue if necessary) and then to convey basic German to them. A maximum of 240 hours is financed, with classes being split into three blocks of 60 to 80 hours each. A maximum of 20 hours per week can be taught.

c. Intensive language courses are offered on a basis of 10 to 20 hours per week of intensive training. They follow a specific goal, e.g., a certificate, preparation for an apprenticeship, a job, or further occupational training. These courses consist of three consecutive courses of 60 to 240 hours for a total of not more than 640 hours.

All of these courses can also be conducted as purely female courses with more taskoriented classes and "women-specific" topics. Child minding will be funded if at least five children are present in the household. Participants cannot take more than one course type at any one time, and failed courses can only be repeated once.

After participating in the basic or intensive language courses, participants can take a special course called Grundbaustein-Kurs, leading to the attainment of an internationally recognized examination (Grundbaustein-Prüfung). The duration of the course is a total of 60 hours, with a maximum of 20 hours a week. These courses are offered in particular by adult education centres (Volkshochschulen), which account for more than one third of all language courses and presently employ about 2,400 language (course) instructors nationwide.

Social Consult GmbH, Infratest Burke Sozialforschung GmbH and Fachbereich Deutsch als Fremdsprache, Universität Essen conducted an extensive survey of the Ausländer language courses including a survey of former and current participants of the various programs. The following is a brief description of their results. ${ }^{55}$

The survey examined 344 service providers. Most of these service providers offer additional courses not funded by the Sprachverband. Overall, the dependence on funding from the Sprachverband is fairly low. Most service providers rely on their own funding, tuition fees, or other subsidies. The majority of courses (roughly 40\%) start at a very low level, which leads to the conclusion that the initial German language proficiency of most participants is low. Almost all service providers (96.4\%) issue certificates of participation after completion of the 
course, but only 6.8 percent issue primitive transcripts or report cards. Furthermore, only 21 percent of service providers use standardized tests to determine whether participants have met the course requirements, and most service providers rely on more informal evaluation methods including assessment by the course leader and simple completion of a certain chapter in the textbook.

Most service providers estimate that their courses contribute significantly to the social (72.7\%) and economic (57.4\%) integration of Ausländer. With respect to areas of improvement, service providers would like to see a broadening of the target group because a large number of potential students is not eligible for funding through the Sprachverband. Thus, the number of eligible participants has declined, while the overall demand for language training has increased. Therefore, most service providers also demand more autonomy in the allocation of funds to facilitate greater flexibility in the range of courses offered.

A survey of current and former language course students indicated that their primary motivation for acquiring German was to be able to better cope with everyday life. The second reason was to improve the chances of finding employment, closely followed by a desire to improve their contact with German citizens. Table 10 contains a detailed list of self-reported motivations for language course participation.

Table 10: Ausländer Motivations for Participation in a German Language Course

\begin{tabular}{|l|c|c|}
\hline Main reason & $\begin{array}{l}\text { Current } \\
\text { Participants }\end{array}$ & $\begin{array}{l}\text { Former } \\
\text { Participants }\end{array}$ \\
\hline To better cope with everyday life & $45 \%$ & $51 \%$ \\
\hline To improve chances of finding work & $22 \%$ & $11 \%$ \\
\hline To improve contact with Germans & $18 \%$ & $12 \%$ \\
\hline To better cope with the workplace & $11 \%$ & $5 \%$ \\
\hline To keep the current job & $1 \%$ & $0 \%$ \\
\hline Other & $4 \%$ & $21 \%$ \\
\hline
\end{tabular}

Source: Infratest Burke Sozialforschung (in: Social Consult Survey, 1998)

\footnotetext{
${ }^{55}$ For an in-depth analysis, see Dorfmann et al. (1999).
} 
Furthermore, former language course participants were asked whether the language courses did indeed help them achieve their goals. About 90 percent believed they did, either significantly or at least to some extent. When asked to judge their improvement in language proficiency, most current participants believed that their language skills have improved significantly (47\%) or somewhat (49\%). A similar response pattern applies to former language course participants (43\%: improved significantly, 48\%: improved somewhat).

Only 20 percent of the participants took a placement examination. However, most of them argued that initial assessment tests would allow the service provider to better group participants according to their proficiency level. Furthermore, while almost none of the service providers administered final exams, the overwhelming majority of course participants (about $75 \%$ ) believed a final exam should be conducted, at least on a voluntary basis.

Like in Canada, some occupational groups require a certain degree of linguistic competence for registration of foreign applicants. For example, for registration as a physician in Germany, among other prerequisites, "sufficient" German language skills are required from the applicant if s/he is not a national of an EU country. ${ }^{56}$ Specifically, they have to pass the Mittelstufenprüfung (Intermediate Level exam) in order to obtain the required language certificate. In most cases, the accompanying language course, offered by the Goethe Institute and adult education centres, has to be attended for at least six months to prepare for the exam. Arising fees have to be fully paid by the applicants. However, EU citizens can register without knowing any German at all. This anomaly leads to the possibility that an exceptional Iranian physician could not immediately practice in Germany, while a less qualified physician from Italy could.

German is the language of instruction at all German universities and Fachhochschulen. Thus, foreign students not only have to pass a general assessment test (Feststellungsprüfung) in order to meet the formal conditions for admittance to studies in Germany, but also are obliged to pass the Deutsche Sprachprüfung für den Hochschulzugang ausländischer Studienbewerber

\footnotetext{
${ }^{56}$ Cf. e. g. Ministerium für Arbeit, Gesundheit und Soziales des Landes Nordrhein-Westfalen (1994), 782.
} 
(DSH), or German language examination prior to university admittance. ${ }^{57}$ Applicants who hold a higher education entrance qualification of a recognized school in which German is the language of instruction or possess other language certificates ${ }^{58}$ - mainly awarded by the Goethe Institute are excused from the $D S H$.

Since the $D S H$ is part of the general assessment test, preparatory courses for this examination (Studienkollegs) include language courses as well. Before being accepted to a Studienkolleg, the applicants have to prove sufficient competency in German (Mittelstufe II or Intermediate Level II). ${ }^{59}$ The Studienkollegs usually last for two semesters (one year), culminating in a general assessment test. Weekly courses include 10-12 hours of language instruction and about 20 hours of subject-related instruction. The $D S H$ test, which can be taken at any time, consists of written and oral components. Applications of examinees who fail the German language section will automatically be rejected. Re-application is possible only once.

\section{Preliminary results}

The already mentioned new "Gesamtsprachkonzept" is meant to unite the separated language programs for Aussiedler and Ausländer into one official language-training program for all new permanent immigrants in the medium term. The regulations that are incorporated in the new immigration act clearly show that the separate treatment of Aussiedler (language test prior to entry) and Ausländer (language course offers after entry) will not be discarded altogether. However, the immigration act will create an incentive to acquire language skills before application or entry: It provides for an assessment of language skills within the point system, the recompensation of successful participation in integration courses with the shortening of the residence requirement prior to naturalization by one year, and the requirement to attend language and integration courses if the applicant is not able to communicate in German "on a basic level".

\footnotetext{
${ }^{57}$ For details, see Deutscher Akademischer Austauschdienst/Fachverband Deutsch als Fremdsprache (1998).

${ }^{58}$ Deutsches Sprachdiplom, Stufe II. der Kultusministerkonferenz, Kleines deutsches Sprachdiplom/Großes deutsches Sprachdiplom, Zentrale Oberstufenprüfung.

${ }^{59}$ In addition, most universities offer language courses to prepare for the Studienkollegs and DSH. In contrast to the courses provided by the Goethe Institute, these courses are free of charge. Admission capacity is limited, and the required level of pre-course language skills varies. Thus, universities strongly recommend that applicants acquire at least a certain amount of linguistic competency in the home country through courses offered by the Goethe Institute.
} 
In this context, however, particular attention should also be paid to foreigners who have already lived in Germany for a long time and whose language skills are often insufficient. ${ }^{60}$

${ }^{60}$ In the current debate, the lack of language proficiency especially of first-generation immigrants in Germany is often overlooked. The immigration act does not contain any special provisions for this group. Cf. Frick/Wagner (2001). 


\section{Evaluation of Second Language Acquisition in Canada and Germany}

This review of both Canada's and Germany's language programs for immigrants raises the question which approach is more effective. Two distinct models of second language acquisition exist in the two countries - however, given recent legislative activity in Germany and Canada, similarities between the two models seem to be growing to a certain extent. Canada, in essence, does not require immigrants to acquire knowledge of either official language at any point from entry to citizenship, apart from the fact that the level of linguistic knowledge is assessed in the point system and has gained more importance since the new regulations of entry passed in November 2001. It relies mainly on a market solution to achieve an optimal acquisition of a second language by immigrants. Germany, on the other hand, has explicitly used second language acquisition since 1996 as a screening device and criterion for citizenship for Spätaussiedler and since 2000 as a criterion for citizenship for Ausländer. The new immigration act has also created a legal basis for the assessment of language skills within a point system before entry. In addition, a myriad of state agencies offer subsidized language training through a variety of programs to facilitate integration in German society. How do we measure the effectiveness of each approach?

DeVoretz and Werner (1999) offer a theoretical framework for measuring optimal immigrant second language acquisition across a variety of activity milieus (economic, social, educational and political). The central point to be drawn from their discussion is that no one level of immigrant second language acquisition is optimal in any one sphere. Within each sphere, individuals - independently of government compulsion or subsidies - will voluntarily acquire a mix of second language skills depending on their individual characteristics. The empirical data in both Canada and Germany yield a measure of the relative returns from second language acquisition in the respective labour markets under these two regimes. 
Table 11: Rates of Return based on Second Language Proficiency in Canada

\begin{tabular}{|c|c|c|c|c|c|}
\hline Author(s) & Data Period & & $\begin{array}{r}\text { Impact on } \\
\text { Earnings (in } \\
\end{array}$ & & $\begin{array}{c}\text { Impact on } \\
\text { Employment (in \%) }\end{array}$ \\
\hline \multirow{3}{*}{$\begin{array}{l}\text { Chiswick and } \\
\text { Miller (1988) }\end{array}$} & \multirow{3}{*}{1981} & \multirow[t]{2}{*}{ Bi-ling. } & Engl. only & French only & Mother Tongue Only \\
\hline & & & QUE ROC & QUE ROC & N/A \\
\hline & & +18 & $+7.8 \quad 12.1$ & $+4.5+17.9$ & \\
\hline $\begin{array}{l}\text { Chiswick and } \\
\text { Miller (1992) }\end{array}$ & $\begin{array}{c}1981 \\
\text { (males } \\
\text { only) }\end{array}$ & \multicolumn{3}{|c|}{+12.2} & N/A \\
\hline Boyd (1990) & $\begin{array}{c}1986 \\
\text { (females } \\
\text { only) }\end{array}$ & \multicolumn{3}{|c|}{+17.1} & +4.6 \\
\hline \multirow[t]{2}{*}{$\begin{array}{l}\text { DeSilva } \\
(1997)\end{array}$} & 1980’s & +25 & +26 & -3 & \\
\hline & & Chinese & $\begin{array}{l}\text { Asian Non- } \\
\text { Chinese }\end{array}$ & Other European & \\
\hline \multirow{3}{*}{$\begin{array}{l}\text { Pendakur and } \\
\text { Pendakur } \\
\text { (1997) }\end{array}$} & Montreal & +4 & \multirow{3}{*}{ NA } & -1 & -17 \\
\hline & Toronto & +3 & & +6 & -16 \\
\hline & Vancouver & -1 & & -2 & -9 \\
\hline
\end{tabular}

Table 11 provides a summary of findings of selected studies conducted in Canada over the past two decades to test the association between immigrant second language acquisition and their labour market performance. The reported studies indicate that a proficiency in one or both of Canada's official languages has a consistently positive effect on both immigrant earnings and employment opportunities. Regardless of the second language acquired (French or English), gender, and ethnicity of the immigrant, the rates of return from second language acquisition are extremely large. For example, for either female or male immigrants, earnings rose from 12.2 to 17.1 percent for each year after the immigrant acquired a second language. These returns are averages across all skill levels, and there is no doubt that the rates of return are even higher for skilled and professionally trained immigrants. ${ }^{61}$ Pendakur and Pendakur (1997) further find that in Canada "mother-tongue language knowledge is correlated with poorer labour market outcomes" since the "vast majority of the people who speak non-official languages are part of the ethnic language community." This observation is reinforced by their finding that proficiency in a non-official language only reduces immigrant earnings in Toronto and Montreal by 16 to 17 percent, respectively. In sum, the Canadian labour market rewards second language acquisition and penalizes unilingual mother tongue knowledge. 
The empirical evidence on the interdependence between German language acquisition and earnings performance is partially documented by Dustmann (1997) and Schmidt (1997). Schmidt reports that the earnings of ethnic Germans equal that of native West Germans because Aussiedler and native West Germans have identical human capital endowments. However, Schmidt notes that Ausländer earn substantially less than Aussiedler due to the low educational attainment of Ausländer. Schmidt concludes from the effect of linguistic differences on earnings differentials between native West Germans and Aussiedler that there is no return on "countryspecific human capital over time" for the Aussiedler. In other words, improved German language skills after arrival do not improve Aussiedler earnings relative to native West Germans.

Even more interesting is Schmidt's finding that when controlling for education, the earnings difference between Ausländer and Aussiedler collapses. This finding implies that the return to second language acquisition is minimal for Ausländer. However, second language acquisition and education are complementary, and Schmidt's findings indirectly confirm that German language acquisition and education have substantial potential returns for Ausländer when acquired jointly. Dustmann (1997) confirms this point by showing that parental education positively affects the acquisition of German language skills by foreigners. In sum, both studies indicate that language and education are complementary human capital inputs, thereby raising foreign workers' wages in Germany.

\section{Social Sphere}

In the social environment, DeVoretz and Werner (1999) further argue that knowledge of the dominant second language leads to tangible networking benefits for the immigrant and enhances integration. This is especially true for immigrant youth, who are at the crucial point of socializing and selecting a possible marriage partner. Second language acquisition increases the likelihood of social and marriage integration and reduces the likelihood of continued "chain migration" to facilitate marriage. In the Canadian context, it has been found that male immigrants with minimal second language skills are more likely to "import" a bride than to seek a marriage partner within the Canadian community. Similar circumstances appear in Germany. Network effects and German language deficiencies lower the incentives for language acquisition

\footnotetext{
${ }^{61}$ DeVoretz/Werner (1999).
} 
and social contacts with Germans considerably. For example, in predominantly urban Turkish neighbourhoods it is possible to interact entirely in Turkish. This linguistic isolation can lead to a "ghettoization" of different cultures, isolating the foreign community from mainstream German society and disturbing the process of social integration. Moreover, an inverse relationship exists between the length of stay in Germany and the degree of language competency. The longer immigrants stay in Germany without taking language courses, the less likely they are to further their knowledge of German. Without formal training, the limited German they know has been acquired "on the streets" and is often not adequate to function in a broad social context. The situation of the immigrants' children is different as they learn German in school and often possess important bilingual and bicultural competencies. Still, some young "immigrants" (especially those who migrated as youth and have only a short schooling history in Germany) still face integration problems due to German language deficiencies. The process of language acquisition often remains incomplete as a result of families' ephemeral goal of return migration to the home country. In other cases, linguistic and social "ghettoization" of youth with a foreign background may result from a half-hearted German integration policy towards these young people living "between two worlds". 62

\section{Economic Sphere}

As mentioned above, both the Canadian and the German labour market require a certain degree of language skills in order to register for several occupations. In Germany, however, substantial language skills are only required for high-skilled occupations. For less skilled work only a rudimentary knowledge of spoken and written German is required. For example, to work as a cleaning lady in Germany, rudimentary German is sufficient to find a job, but clearly insufficient for social integration. Foreign physicians, on the other hand, need a very high level of both spoken and written German, which facilitates complete social integration.

\footnotetext{
${ }^{62}$ For a general description of the social and labour market situation of youth and adult foreigners living in Germany, see the special report provided by the Federal Government's Commissioner for Foreigners' Issues (Bericht zur Lage der Ausländer in der Bundesrepublik Deutschland). A German edition of the 2000 report is available at www.bundesauslaenderbeauftragte.de/publikationen/index.stm.
} 
In this context, the following questions arise: Should the same language standards apply to both individuals? Should there be a mandatory language level in order to insure social integration? Or should the level of language competency be indicated by the market?

\section{Political Sphere}

Canada and Germany both mandate a minimum level of second-language proficiency for citizenship. At present, "Spätaussiedler" in Germany represent a special group. Prior to their acceptance and entry they have to take a language test, but after their arrival they automatically become naturalized. This constitutes a problem especially for younger family members, who often have very poor knowledge of German but are not required to take any language test. This means that their citizens' rights, most notably the right to vote and the eligibility for political office, are not attached to sufficient German language skills.

Proficiency in the German language has not been obligatory for foreigners who do not seek naturalization. In this respect, the implementation of the long-disputed immigration act would signify a fundamental change, at least for all future immigrants. With regard to political participation, the new law does not imply any changes for the majority of the foreigners living in Germany. Regardless of individual language skills, political participation will still not be possible for those who abandon naturalization for personal reasons or who belong to a group for which naturalization is still legally impossible. With the exception of the active and passive voting rights on a local level, which citizens of the European Union are allowed to exercise at their place of residence within the EU, naturalization is the basic requirement for suffrage and political candidacy. The widespread "Ausländerbeiräte" (advisory councils for foreigners) have rather poor political hearing and participation rights. In the past, non-EU citizens who had been living in Germany for a long time and may have had acquired good language skills therefore often felt excluded from the political process. Others also blamed missing participation possibilities for their poor language skills.

The fact that to date Germany has not officially declared itself an immigration country has also kept many immigrants from realizing the permanence of their stay, and reduced their willingness to learn the language. This has contributed to the relative reluctance of immigrants to make use of their right to naturalization, which under German law usually requires giving up 
one's original nationality. The kind of "political apathy" that can be noticed among some foreign residents in Germany is caused to a large extent by the subjectively felt inconsistency of social integration programs and the absence of influential lobbying structures. Since the minimum residence requirement prior to acquiring German citizenship was lowered from 15 to 8 years, however, these complaints have lost their relevance. In fact, not only the naturalization figures have increased significantly, but the political parties also make a greater effort to attract naturalized immigrants to their organizations.

In Canada, active participation in the political process also requires Canadian citizenship, which means that at least basic language skills must exist. Candidacy for parliament requires additional knowledge of the official languages. Ethnically homogenous voting blocs or parties play an insignificant role. Promising candidates generally belong to the larger mainstream parties. In turn, these parties have a vital interest in nominating naturalized candidates in order to successfully compete for ethnic voters. As a result, immigrants of different ethnic origin are relatively well represented in Canadian parties. In the 1990s, for example, the entire parliament fraction of the governing party in the province of British Columbia consisted of foreign-born, naturalized representatives.

Germany, in comparison, still lacks this relatively uncomplicated manner of dealing with naturalized political candidates and voters. The modified naturalization law and the prospect of better integration incentives within the scope of the new immigration act may allow Germany, though, to gradually approximate the Canadian situation. The more emphatically language acquisition is promoted by such incentives, the more unfounded seems the concern that "excessive" language requirements could induce political ghettoization and jeopardize integration. 


\section{Summary and Conclusion}

This comparative analysis of language training in Canada and Germany presents two possible models for immigrant second language acquisition. The German model, which has been statist until now, relies on formal linguistic assessment criteria for entry of Spätaussiedler and for naturalization of Ausländer. If the new immigration law enters into force in 2003, an assessment of foreign immigration applicants' language proficiency through a point system, additional incentives for language acquisition due to a (slightly) shorter residence requirement prior to naturalization, compulsory attendance of language and integration courses for immigrating foreigners without "basic" language skills as well as the inclusion of family members of potential Spätaussiedler into language testing prior to entering Germany are added. Other language requirements are limited to certain occupational groups or requirements in cases of individually chosen education.

Under the Canadian model, the government's influence on immigrants' language acquisition has grown in importance, but is still rather weak. It is possible to enter Canada and even become a citizen without oral or written knowledge of either official language if the required number of points in the point system is reached. However, recent Canadian legislation has emphasized the language criterion. If immigrants do not acquire language skills in order to have an advantage within the point system, second language acquisition is mostly voluntary and depends on the social, educational and labour market incentives. Government intervention happens only indirectly via linguistic educational subsidies.

Canadian voluntary and individually motivated language acquisition suffers from the initial drawback first developed theoretically by DeVoretz and Werner (1999). In a voluntary system of language acquisition in the absence of subsidies, the default equilibrium second language acquisition in the labour, political and social spheres will be minimal oral second language acquisition skills. Mature first-generation immigrants in particular may never acquire functional second language skills in Canada. This dramatic shortcoming could be overcome by a loan program for second language acquisition. Under these conditions, skilled or professionally qualified immigrants would receive a loan in order to improve their language skills to a degree that they regard as beneficial in the social, labour or political spheres. Especially in the labour 
market this loan scheme would have to be sufficiently generous to enable immigrants to acquire second language skills to pass the appropriate qualifying exams.

The advantage of the Canadian system is that young and well-off immigrants can reach an optimal level of second language acquisition, which they perceive as an investment that will be rewarded in the labour market. They will continue to acquire second language proficiency until this investment on the margin is no longer rewarding. In the event that discrimination or macro labour market conditions (unemployment) prevent immigrants from realizing their returns, the contingent nature of the repayment scheme removes any risk. ${ }^{63}$

What are the drawbacks of this voluntary model? Language acquisition benchmarks must exist and to be well known to potential employers or other interested parties so that the level of language acquisition can be easily tested. Certification of results, training appropriate for the task at hand and employer recognition are also essential ingredients. In the absence of one of these, individual immigrants will not make the investment in second language acquisition because their expected rewards will not be realized.

Would this model work in the German context, or should the Federal Republic instead concentrate on developing a uniform language screening system for both Aussiedler and Ausländer to be administered after entry into the country? The statist model of second language acquisition would be a logical solution if the only policy objective were naturalization of all immigrants, Aussiedler as well as Ausländer. However, since German politics should aim at controlling immigration by means of a selection process, a modified version of Canada's second language acquisition model seems appropriate.

In the German context, it is not sufficient, though, to rely solely on voluntary language acquisition. The acquisition of a certain degree of German language skills at an early stage after entry appears to be desirable for several reasons. Canada's laissez-faire policy works because English, one of the two official languages, is an international language, which means that it is fairly likely that immigrants possess at least some knowledge in English. For Germany, the reverse is true. Furthermore, the incentive to acquire knowledge in German is comparatively low

\footnotetext{
63 The contingent loan scheme operates in such a fashion that the repayment (zero to 100 percent of the loan) is contingent upon earnings after the second language skill is acquired.
} 
if further migration, e.g. to the US or Canada, is planned. Also, given the higher influx of immigrants into Germany, the resulting integration problems cannot be solved exclusively by voluntary in-country language acquisition - additional measures are essential for successful integration.

The sooner immigrants meet basic German language standards, the faster social integration will occur. In this regard, the criterion of language skills measured by a point system for the evaluation of applications for immigration (which is included in the new German immigration act) seems the plausible solution. Within such a system it is vital, though, not to give too much weight to language knowledge. This would mean paying too high a price for better integration as it would further increase the probability for the "best brains" to migrate elsewhere.

After entry into Germany, a voluntary second language acquisition model appears to be a realistic approach to meet both the individuals' needs and the common interest in facilitating social integration. In addition, a system of positive incentives regarding the waiting period until naturalization and greater labour market mobility would improve Germany's language policy. Furthermore, an effective incentive could be set through a deposit system as it is in practice in Australia. Those failing an initial language test would have to pay such a deposit, which would be fully refunded if the immigrant successfully passes a language course or a second test within a fixed period.

The Federal Government established an independent expert commission on migration issues in 2000 ("Unabhängige Kommission Zuwanderung der Bundesregierung”). Its report not only emphasized the necessity of a comprehensive German immigration law, but highlighted the importance of language proficiency of foreigners. ${ }^{64}$ In the meantime, several proposals have been published which should further the discussion on language. For example, the Sprachverband Deutsch für ausländische Arbeitnehmer has criticized previous government language programs for not having reached every immigrant and establishing a separation line between Ausländer and Aussiedler. According to the Sprachverband proposals, all permanent immigrants including

\footnotetext{
${ }^{64}$ For details, see Unabhängige Kommission Zuwanderung (2001).
} 
those already living in Germany should be entitled to complete 600 hours of language training. ${ }^{65}$ Moreover, the Sprachverband argues that participants should contribute to the funding. The problem will be, however, to secure attendance of those who obviously lack language skills. Positive incentives through modifications of the German work permission and naturalization law will be necessary to ensure the effectiveness of such a program.

In this context, the German Federal Government's Commissioner for Foreigners' Issues recently proposed "integration contracts" between permanent immigrants and federal authorities. $^{66}$ Among other features, immigrants would receive an integration voucher (Integrationsscheck) to be "cashed" for language and integration course modules on a flexible basis meeting the individuals needs. If these vouchers are used within three years of entering the country, residence and work permits and naturalization will be expedited. This concept has already been successfully implemented in the Netherlands and should receive more attention in the German debate. To be sure, implementation costs are estimated to be almost double the previous expenditures (about $€ 315$ million $/ \$ 446$ million $\mathrm{Cdn}$.), but the concept is highly functional. In particular, it would introduce positive and transparent incentives, which the German system of language acquisition lacks so far.

Several studies have shown that acquisition of linguistic knowledge alone is not sufficient for improving the income situation of foreign employees relative to the one of native employees on the German labour market. Rather, increased linguistic knowledge has to be combined with a higher level of educational and/or vocational knowledge in order to reach this effect. Language acquisition and education are complementary, a fact that an appropriate language policy has to take into account.

It is hard to assess whether the planned Gesamtsprachkonzept for the organizational and substantial homogenization of language policy for Ausländer and Spätaussiedler, which has been anticipated by the new immigration act, will really improve immigrants' linguistic knowledge. On the one hand, the new structure of language training will presumably lead to an increasing number of immigrants entitled to attend language courses. The government expects 14,000

\footnotetext{
${ }^{65}$ For details, see Sprachverband Deutsch für ausländische Arbeitnehmer e. V. (1999).

${ }^{66}$ For details, see Beauftragte der Bundesregierung für Ausländerfragen (2000c).
} 
participants per year additional to the original yearly average of 96,000. On the other hand, government funding will probably remain at the previous level. Moreover, a very heterogeneous group of ethnic German and foreign immigrants will be confronted with a uniform language standard. At the same time, the new general language concept aims at assembling more homogeneous participant groups according to vocational and educational aspects and previous knowledge of German language than in the past. Multiple support based on the current rather confusing training system shall be avoided, synergy effects as a result of organizational reform are hoped for. Future German language training, according to the Gesamtsprachkonzept, will fall within joint interdepartmental competence of the Bundesministerium für Arbeit und Sozialordnung (BMA) and the Bundesministerium für Familie, Senioren, Frauen und Jugend (BMFSFJ). While BMA will be responsible for all training meant for immigrants older than 27 years, BMFSFJ will have jurisdiction concerning young immigrants. It cannot be predicted whether or not this new concept will lead to a strengthening of language proficiency. At least, intensified quality evaluation is part of the Gesamtsprachkonzept and could help achieve a more effective overall language training.

To secure a successful language program in the future, language course participants could contribute to the expenses, which would create a positive learning incentive. The new German immigration act does provide for this possibility. This kind of burden-sharing could easily be combined with a deposit system. This strategy appears to be more convincing than an extension of the principles of Aussiedler language assessment structures to include Ausländer. Additional to increased organizational costs, this would require a conclusive set of incentives in order not to reduce Germany's attractiveness as a competitive immigration country, but to promote potential immigrants' interest in acquiring a certain degree of German language skills prior to entry even before being accepted for immigration. It is doubtful whether this concept would work. In this context, the plausibility of compulsory attendance of language and integration courses in cases of insufficient basic language skills provided for in the new immigration act appears problematic. A more convincing strategy seems to be a connection of course attendance or private initiative for all groups of immigrants with corresponding positive incentives. Such a system of incentives would very likely be superior to a threat of sanctions. However, the shortening of the residence requirement by one year prior to legal entitlement to naturalization in the case of successful 
attendance of an integration course, which is provided for in the immigration law, seems insufficient.

Furthermore, only a stringent mechanism of incentives will facilitate convincing effects of the procedure chosen after the Canadian model: It will enable authorities to select immigrants according to a point system that rewards language knowledge besides labour market suitability (on the basis of the respective certificates) without overemphasizing language skills in relation to other qualifying criteria. Then, a stringent strategy of incentives to accelerate and enhance language acquisition in Germany is essential in this regard.

A reformed language policy for Germany could combine the Canadian and the German models to a general concept, which, on the one hand, would retain the principle of voluntary participation and the necessary flexibility of immigrants. On the other hand, however, it would speed up and improve the process of language acquisition - to the benefit of society and the labour market. A common language is the key to social cohesion in an open German society, which has only begun to identify with its status as an immigration country. 


\section{References}

Bauer, T. (2002), Migration, Sozialstaat und Zuwanderungspolitik, IZA Discussion Paper No. 505. Bonn: IZA.

Boyd, M. (1990). Immigrant Women: Language, Socioeconomic Inequalities, and Policy Issues. In: Halli, S./F. Trovato/L. Driedger (Eds.), Ethnic Demography - Canadian Immigrant: Racial and Cultural Variations, 275-95. Ottawa.

Canada. College of Physicians and Surgeons of British Columbia. (1997). Rules Made under the Medical Practitioners Act. Vancouver.

Canada. CIC/Department of Citizenship and Immigration (1996a). Canadian Language Benchmarks: ESL for Adults and ESL for Literacy Learners. http://cicnet.ci.gc.ca/english/newcomer/esl-e.html.

Canada. CIC/Department of Citizenship and Immigration (1996b). News Release. Canadian Language Benchmarks unveiled. http://cicnet.ci.gc.ca/english/press/96/9612-pre.html.

Canada. CIC/Department of Citizenship and Immigration (1997). Language Instructions for Newcomers to Canada - Guide for Applicants. http://cicnet.ci.gc.ca/english/newcomer/linc-2e.html.

Canada. CIC/Department of Citizenship and Immigration (1998). Not Just Numbers - A Canadian Framework for Future Immigration. Minister of Public Works and Government Services Canada, Ca. No. Ci 63-21/1998E. Ottawa.

Canada. CIC/Department of Citizenship and Immigration. (1999a). A Look at Canada. Minister of Public Works and Government Services Canada, Ca. No. Ci 51-61/1999E. Ottawa.

Canada. CIC/Department of Citizenship and Immigration (1999b). Internal documents.

Canada. National Committee on Accreditation. (1999). Evaluation of Legal Credentials for Accreditation. http://www.flsc.ca/english/publications/ncaguidelineseng.pdf.

Canada. Ontario College of Pharmacists (1997). Occupational Fact Sheet for Foreign Trained Pharmacists. http://www.ocpharma.com/Registration/outprov.asp.

Canada. Statistics Canada (1997). The Nation Series. Census 1996: Cat. 93F0023XDB96005.

Chapman, B./R. Iredale (1993). Immigrant Qualifications: Recognition and Relative Wage Outcomes. International Migration Review 27, no. 2: 359-87.

Chiswick, B. (Ed.) (1992). Immigration, language and ethnicity: Canada and the United States. Washington.

Chiswick, B./Y. Lee/P. Miller (2002). Immigrants' Language Skills: The Australian Experience in a Longitudinal Survey, IZA Discussion Paper No. 502. Bonn: IZA.

Chiswick, B./Y. Lee/P. Miller (2002). Immigrants’ Language Skills and visa Category, IZA Discussion Paper No. 471. Bonn: IZA. 
Chiswick, B./P. Miller (1988). Earnings in Canada: The Roles of Immigrant Generation, French Ethnicity and Language. Research in Population Economics 6: 183-224.

(1995). The Endogeneity between Language and Earnings: International Analyses. Journal of Labour Economics 13, no. 2: 247-89.

(1999a). Language practice and the economic well-being of immigrants. Policy Options, 45-50.

(1999b) Immigration, Language and Multiculturalism in Australia, Australian Economic Review, 32(4), December 1999: 369-85.

Cohen, S./Z. Eckstein (2002). Labor Mobility of Immigrants: Training, Experience, Language and Opportunities, IZA Discussion Paper No. 519. Bonn: IZA.

DeSilva, A. (1997). Earnings of Immigrant Classes in the early 1980s in Canada: A Re-Examination. Canadian Public Policy 23, no. 2: 179-99.

DeVoretz, D./S. Laryea (1997). Canadian Immigration Experience: Any Lessons for Europe?, IZA Discussion Paper No. 59.Bonn: IZA.

DeVoretz, D./C. Werner (1999). A Theory of Social Forces and Immigrant Second Language Acquisition. RIIM Working Paper 99-22. Burnaby, B.C.: Simon Fraser University, Centre for Excellence: Research on Immigration and Integration in the Metropolis. IZA Discussion Paper No. 110. Bonn: IZA.

Dormann, F./C. Aul/D. Knospe/M. Schlebusch (1998). Sprachförderung von Spätaussiedlern. Bonn: Social Consult GmbH.

Dormann/F./R. Baur/H. Kuwan/K. Rueth/M. Schlebusch/M. Thum (1999). Evaluation der Sprachförderung Deutsch für ausländische Arbeitnehmer. Bonn: Social Consult GmbH.

Dustmann, C. (1994). Speaking Fluency, Writing Fluency and Earnings of Migrants. Journal of Population Economics 7, no. 2: 226-36.

(1997). The Effects of Education, Parental Background and Ethnic Concentration on Language. Quarterly Review of Economics and Finance. Special Issue 37: 345-60.

Fagnan, S. (1995). Canadian Immigrant Earnings 1971-86. In: DeVoretz, D. (Eds.), Diminishing Returns: The Economics of Canada's Recent Immigration Policy, 166-208. Toronto: C.D. Howe Institute, and Vancouver: The Laurier Institution.

Frick, J. R./G. G. Wagner (2001). Deutsche Sprachfähigkeit und Umgangssprache von Zuwanderern. DIW-Wochenbericht 24/01. Berlin.

Gardner, R. G. (1988). The Socio-Education Model of Second Language Learning. Language Learning 38 , no. 1: 101-26.

Germany. Beauftragte der Bundesregierung für Ausländerfragen (1997). Migration und Integration in Zahlen. Ein Handbuch. Bonn.

Germany. Beauftragte der Bundesregierung für Ausländerfragen (1999). Migrationsbericht 1999. Zu- und Abwanderung nach und aus Deutschland. Berlin. 
Germany. Beauftragte der Bundesregierung für Ausländerfragen (2000a). Daten und Fakten zur Ausländersituation. Berlin.

Germany. Beauftragte der Bundesregierung für Ausländerfragen (2000b). Anstöße zum Thema Integration. Berlin. http://www.bundesauslaenderbeauftragte.de/themen/anstoesse.stm.

Germany. Beauftragte der Bundesregierung für Ausländerfragen (2000c). Anstöße zum Thema Integration II. Eckpunkte für eine Integrationsgesetzgebung. Berlin.

http://www.bundesauslaenderbeauftragte.de/themen/anstoesse2.stm.

Germany. Beauftragte der Bundesregierung für Ausländerfragen (2000d). Integration in Städten und Gemeinden. Berlin.

Germany. Beauftragte der Bundesregierung für Ausländerfragen (2000e). Wie werde ich Deutsche/r? Berlin.

Germany. Beauftragte der Bundesregierung für Ausländerfragen (2001a). Mehrsprachigkeit an deutschen Schulen - ein Überblick. Berlin.

Germany. Beauftragte der Bundesregierung für Ausländerfragen (2001b). Migrationsbericht der Ausländerbeauftragten im Auftrag der Bundesregierung. Berlin.

Germany. Beauftragte der Bundesregierung für die Belange der Ausländer (1997). Deutsch lernen (K)Ein Problem. Sprache und Sprachkompetenz als Instrument der Integration. Bonn.

Germany. Beauftragter der Bundesregierung für Aussiedlerfragen (1999-2001). Info-Dienst Deutsche Ausländer. Berlin.

Germany. Bundesgesetzblatt, Teil 1, Nr. 38, June 25, 2002, 1946-2000 (Gesetz zur Steuerung und Begrenzung der Zuwanderung und zur Regelung des Aufenthalts und der Integration von Unionsbürgern und Ausländern/Zuwanderungsgesetz). Bonn.

Germany. Bundesministerium des Innern (1999). Wegweiser für Spätaussiedler. Informationen Beratung - Hilfen. Berlin.

Germany. Bundesverwaltungsamt (1997). Nur Mut - Kleiner Sprachführer für Rußlanddeutsche. Köln.

Germany. Bundesverwaltungsamt. (1999a). Internal documents.

Germany. Bundesverwaltungsamt (1999b). Projekt "Breitenarbeit". Köln.

Germany. Deutscher Akademischer Austauschdienst/Fachverband Deutsch als Fremdsprache (1998), Deutsch als Fremdsprache. Die Deutsche Sprachprüfung für den Hochschulzugang. Bonn.

Germany. Ministerium für Arbeit, Gesundheit und Soziales des Landes Nordrhein-Westfalen (1994). Runderlaß (21. 6. 1994) zur Durchführung der Bundesärzteordnung. Ministerialblatt für das Land Nordrhein-Westfalen, Nr. 47 (26. Juli 1994), p. 778-790.

Germany. Sprachverband Deutsch für ausländische Arbeitnehmer e. V. (1999). Zukünftige Ausgestaltung der Deutschsprachförderung für Zuwanderinnen und Zuwanderer in der Bundesrepublik Deutschland. Mainz. 
Germany. The Federal Government's Commissioner for Foreigners' Issues (1999). Facts and Figures on the Situation of Foreigners in the Federal Republic of Germany. Berlin.

Germany. Unabhängige Kommission Zuwanderung (2001). Zuwanderung gestalten - Integration fördern. Bericht der Unabhängigen Kommission „Zuwanderung“ der Bundesregierung. Berlin.

Green, A./D. Green (1996). The Economic Goals of Canada's Immigration Policy, Past and Present. RIIM Working Paper 96-04. Burnaby, B.C.: Simon Fraser University, Centre for Excellence: Research on Immigration and Integration in the Metropolis.

Hart, D./A. Cumming (1997). Follow-up Study of People in Ontario Completing Level 3 of the Language Instruction for Newcomers to Canada (LINC) Program. Toronto: Ontario Institute for Studies in Education/University of Toronto.

Norton, B./G. Stewart (1999). Accountability in Language Assessment: Challenges in a Canadian Trench. Canadian Modern Language Review 56(2), December 1999: 223-244.

Pendakur, K./Pendakur, R. (1997). Speak and Ye Shall Receive: Language Knowledge as Human Capital. RIIM Working Paper 97-10. Burnaby, B.C.: Simon Fraser University, Centre for Excellence: Research on Immigration and Integration in the Metropolis.

Schmalz-Jacobsen, C./G. Tsapanos/H. Hinte (1993). Einwanderung und dann? Perspektiven einer neuen Ausländerpolitik. München.

Schmidt, C. M. (1997). Immigrant Performance in Germany: Labour Earnings of Ethnic German Migrants and Foreign Guest Workers. Quarterly Review of Economics and Finance 37 (0) Special Issue: $379-97$.

Simmons, A. (1990). "New Wave" Immigrants: Origins and Characteristics. In: Halli, S./F. Trovato/L. Driedger (Eds.), Ethnic Demography - Canadian Immigrant, Racial and Cultural Variations, 141-159. Ottawa.

Sweetman, A. (1999). Language Skills Hold Back Immigrant Kids in Math and Science. Policy Options, $35-38$.

VanPatten, B. (1999). What is Second Language Acquisition and What is it Doing in this Department? ADFL Bulletin 30, no. 3: 49-53.

Zimmermann, K. F. (1998), Immigration und Arbeitsmarkt: Eine ökonomische Perspektive. In: Boesler, K.-A./G. Heinritz/R. Wiessner (Eds.), Europa zwischen Integration und Regionalismus. Stuttgart, $55-66$.

Zimmermann, K. F. (1999). Ethnic German migration since 1989: Results and perspectives. IZA Discussion Paper No. 50. Bonn: IZA.

Zimmermann, K. F./T. K. Bauer/H. Bonin/R. Fahr/H. Hinte (2002), Arbeitskräftemangel bei hoher Arbeitslosigkeit. Ein ökonomisches Zuwanderungskonzept für Deutschland. Berlin/Heidelberg/New York. 


\section{Appendix A}

Excerpts from the German Grundgesetz/Basic Law (as of November 3, 1995)

\section{$\underline{\text { Article } 16}$}

(1) No one may be deprived of his German citizenship. Loss of citizenship may arise only pursuant to a law, and against the will of the person affected it may arise only if such person does not thereby become stateless.

(2) No German may be extradited to a foreign country. Persons persecuted for political reasons enjoy the right of asylum.

\section{Article 116}

(1) Unless otherwise provided by law, a German within the meaning of this Basic Law is a person who possesses German citizenship who has been admitted to the territory of the German Reich, as it existed on December 31, 1937, as a refugee or expellee of German stock or as the spouse or descendant of such person.

(2) Former German citizens who between January 30, 1933 and May 8 1945, were deprived of their citizenship for political, racial or religious reasons, and their descendants, shall be regranted German citizenship on application. They are considered as not having been deprived of their German citizenship if they have established their domicile in Germany after May 8, 1945 and have not expressed a contrary intention.

Source of Translation: International Constitutional Law, internet source (August 13, 1999):

http://www.uni-wuerzburg.de/law/gm00000_html 


\section{Appendix B}

\section{Excerpts from the General Administrative Provisions to the German Citizenship and} Naturalization Law - StAR-VwV (as of January 1, 2000), Cabinet Decision, October 18, 2000

\section{Ausländergesetz (Aliens Act)}

86

86.1

86.1 .1

\section{Ad $§ 86 \quad$ Reasons for Exclusion}

Ad no. 1 (Insufficient knowledge of German)

Knowledge of German is sufficient if the applicant for naturalization is able to find his/her way in daily life with respect to language including usual contact with the authorities in his/her German environment, and if it is possible to communicate with him/her in accordance with his/her age and educational level. This includes also that the applicant is able to read and understand German texts of daily use and to repeat their contents orally. Handicaps that considerably impede the applicant's ability to read or speak have to be taken into account.

Ability to communicate orally in a basic way is not sufficient.

$$
\text { Proof of linguistic proficiency }
$$

Immigration authorities must investigate the reason for exclusion due to insufficient knowledge of German. As a rule, proof of linguistic proficiency is given if the applicant for naturalization

a) acquired the Certificate in German (Zertifikat Deutsch) or any equivalent language diploma,

b) successfully attended a school with German as the teaching language for four years (the end-of-year report must state that the applicant passed, i.e. would have been able to move on to the next class),

c) acquired a first German school degree (Hauptschulabschluß) or an at least equivalent German degree,

d) was put up to tenth grade of a secondary school with German as the teaching language (Realschule, Gymnasium, or Gesamtschule), or

e) acquired a degree from a university or university of applied science (Fachhochschule) with German as the teaching language or completed German vocational training.

If required knowledge of German is not or not sufficiently proved, it is to be ordered that the applicant appear personally for an examination of his/her linguistic proficiency, comp. no. 91.1. Here the requirements of the Certificate of German (Zertifikat Deutsch; ISBN 3-933908-17-5) are an appropriate standard. 


\section{Appendix C}

Excerpts from the German Law on the Control and Limitation of Immigration and the Regulation of the Stay of Foreigners and Integration of EU Citizens and Foreigners (Immigration Act) - June 20, 2002

\section{Article 1: Law on the Stay, Gainful Employment, and Integration of Foreigners in the Territory of the Federal Republic of Germany (Law on the Stay of Foreigners)}

\section{Chapter 2: Entry and Stay in the Federal Territory}

\section{Section 4: Stay for the Purpose of Gainful Employment}

\section{$\S 20$ Immigration via Selection Process}

(1) A residence permit for the purpose of taking up gainful employment is granted if a foreigner has successfully passed the selection process. This also applies to foreigners who are already legally staying in the federal territory.

(2) The selection process is implemented in the economic and scientific interest of the Federal Republic of Germany and serves the purpose of immigration of qualified individuals who are able to work and can be expected to contribute to the economic development and to be integrated successfully into the circumstances of life in the Federal Republic of Germany. The selection is carried out through a point system with special consideration of citizens of those countries with which negotiations on membership in the European Union have been opened.

(3) The Federal Government is authorized to determine by ordinance with consent of the Bundestag and the Bundesrat the conditions for participation in the selection process, the general criteria for the selection of immigration applicants, the evaluation through a point system, and the details of the process. Minimum requirements for participation include a good state of health, a positive reputation, a secure livelihood, and completed professional training. The selection of immigration applicants requires an evaluation of at least the following criteria:

1. Age of the immigration applicant,

2. Qualification in terms of schooling and training as well as work experience of the immigration applicant; [...]

3. Marital status of the immigration applicant;

4. Language proficiency of the immigration applicant;

5. Ties to the Federal Republic of Germany;

6. Country of origin.

In the selection of immigration applicants the share of women and men has to correspond to their respective share of applications. 
(4) The selection process is only carried out after the Federal Office for Migration and Refugees and the Federal Employment Service, after consultation with the Immigration Council (§ 76), have jointly determined a quota for immigration via the selection process.

$[\ldots]$

\section{Chapter 3: Advancement of Integration}

\section{$\S 43$ Integration Course and Integration Program}

(1) Integration of legal and permanent foreign residents in the federal territory into the economic, cultural and social life in the Federal Republic of Germany is supported by the government.

(2) Integration efforts of foreigners are supported by a basic program for integration (integration course). The integration course contains programs that introduce foreigners to German language, law, culture, and history. This is to make foreigners sufficiently familiar with the circumstances of life in the federal territory so that they can act independently in all matters of daily life without the help or intervention of third persons.

(3) The integration course consists of a basic and an advanced language course of equal duration for the acquisition of sufficient language proficiency as well as an orientation course for the communication of knowledge on German law, culture, and history. Successful participation is proven by a certificate issued by the organization providing the language training. Participation in the basic language course is usually prerequisite to participation in the advanced language course. [...] Based on their ability, the participants of the integration course may be required to share some of the costs. [...]

\section{$\S 44$ Entitlement to Participation in Integration Course}

(1) A foreigner who for the first time obtains a residence permit

1. for the purpose of taking up gainful employment [...],

2 . for the purpose of family reunification [...],

3. for humanitarian reasons $[\ldots]$ or

4. without attachment to a particular purpose of stay [...]

when he or she stays permanently in the federal territory is entitled to a one-time participation in an integration course. [...] A foreigner who obtains a unlimited residence permit [...] is also entitled [...] to an integration course. Exempt are children, youth, and young adults who take up schooling or continue their schooling in the Federal Republic of Germany. $[\ldots]$

\section{$\S 45$ Requirement of Participation in an Integration Course}

(1) A foreigner who is entitled to participation in an integration course according to $\S 44$ is required to participate if he or she is not able to communicate in German on a basic level.

(2) When issuing the residence permit establishing the entitlement to participation, the aliens department determines whether the foreigner is required to participate. 
(3) A foreigner's participation requirement according to no. 1 has to be waived completely or in part if

1. he or she is in the process of completing vocational or other training in the federal territory,

2. he or she can prove participation in equivalent educational programs in the federal territory, or if

3. his or her participation is impossible or unreasonable in the long run.

$[\ldots]$

\section{Article 5: Amendment to the Citizenship Act}

The Citizenship Act [...] is amended as follows:

$[\ldots]$

7. After $\S 9$, the following $\S \S 10$ to $12 \mathrm{~b}$ are added:

\section{$\S \mathbf{1 0}$}

(1) A foreigner who has resided legally in the country for a period of eight years is to be naturalized if he or she

1. shows loyalty to the liberal democratic order of the Basic Law of the Federal Republic of Germany and declares that he/she does not pursue or support and has not pursued or supported any endeavors that are directed against the liberal democratic order, the continued existence or the security of the Federal Republic or of a Land [...].

2. is a citizen of the European Union entitled to freedom of movement or citizen of an EEA country treated equally $[\ldots]$.

4. renounces or loses his/her current citizenship [...].

(3) If a foreigner has successfully participated in an integration course according to $\S 43$ of the Law on the Stay of Foreigners, the minimum residence requirement is reduced to seven years according to no. 1 .

\section{$\S 11$}

Entitlement to naturalization according to $\S 10$ does not exist if

1. the foreigner does not have sufficient knowledge of German, [...].

\section{Article 6: Amendment to the Federal Law on Expellees}

The Federal Law on Expellees [...] is amended as follows:

[...]

3. $§ 9$ is changed as follows:

a) The following new no. 1 is inserted:

(1) Spätaussiedler [...] and their spouses or offspring, who meet the requirements [...], are, if they are not subject to mandatory school attendance, entitled to participation in an integration course free of charge that comprises a basic and an advanced language course of equal duration 
for the acquisition of sufficient language proficiency as well as an orientation course for the acquisition of knowledge of German law, culture, and history. With all-day lessons (which is the rule), the duration of the language course is limited to six months.

$[\ldots]$

5. $§ 27$ no. 1 is changed as follows:

[...]

b) Phrases 2 to 4 are as follows:

A non-German spouse living in the country of resettlement, if married for at least three years, or a non-German child $[\ldots]$ are $[\ldots]$ included in the applicant's letter of acceptance only if $[. .$.$] they$ have sufficient knowledge of German and if no reasons for exclusion [...] apply to their person; $[\ldots]$.

Source: Unofficial Translation. 


\section{Appendix D}

\section{Language Support Program for Ethnic Germans and Foreigners in Germany, Status 2000}

\begin{tabular}{|c|c|c|c|c|c|}
\hline Support Program & $S G B I I I$ & $\begin{array}{l}\text { Garantiefonds- } \\
\text { SB }\end{array}$ & Sprachverband & Garantiefonds- $\boldsymbol{H}$ & $\begin{array}{l}\text { Akademiker- } \\
\text { Programm }\end{array}$ \\
\hline $\begin{array}{l}\text { Eligible } \\
\text { Candidates }\end{array}$ & $\begin{array}{l}\text { Ethnic } \\
\text { Germans, } \\
\text { Asylees, } \\
\text { Kontingent- } \\
\text { flüchtlinge }\end{array}$ & $\begin{array}{l}\text { Ethnic Germans, } \\
\text { Asylees, } \\
\text { Kontingent- } \\
\text { flüchtlinge } \\
\text { (under } 27 \text { years } \\
\text { of age) }\end{array}$ & $\begin{array}{l}\text { Foreign Workers } \\
\text { from EU and } \\
\text { Former } \\
\text { Recruitment } \\
\text { Countries } \\
\text { (and Family } \\
\text { Members) }\end{array}$ & $\begin{array}{l}\text { Ethnic Germans, } \\
\text { Asylees, } \\
\text { Kontingent- } \\
\text { flüchtlinge } \\
\text { (under } 30 \text { years of } \\
\text { age) }\end{array}$ & $\begin{array}{l}\text { Ethnic Germans, } \\
\text { Kontingent- } \\
\text { flüchtlinge }\end{array}$ \\
\hline $\begin{array}{l}\text { Type of } \\
\text { Integration }\end{array}$ & $\begin{array}{l}\text { Social } \\
\text { Integration } \\
\text { (incl. Labour } \\
\text { Market) }\end{array}$ & $\begin{array}{l}\text { Schooling and } \\
\text { Occupational } \\
\text { Training }\end{array}$ & $\begin{array}{l}\text { General and Job- } \\
\text { Related } \\
\text { Integration }\end{array}$ & $\begin{array}{l}\text { Integration towards } \\
\text { University } \\
\text { Education }\end{array}$ & $\begin{array}{l}\text { Occupational } \\
\text { Integration }\end{array}$ \\
\hline Overall Units & 903 Units & up to 2000 Units & $\begin{array}{l}\text { up to } 640 \text { Units } \\
\text { (average: } 400 \text { ) }\end{array}$ & 800 Units & up to 420 Units \\
\hline $\begin{array}{l}\text { Length of Support } \\
\text { Program } \\
\text { (Months) }\end{array}$ & 6 & up to 12 & - & 6 & 3 \\
\hline Hours per Week & 35 & up to 40 & $4-20$ & 32 & up to 36 \\
\hline Participants & up to 25 & $15-20$ & $8-20$ & 20 & 20 \\
\hline $\begin{array}{l}\text { Socio-Educational } \\
\text { Care }\end{array}$ & 14 Units (total) & up to $50 \%$ & $\begin{array}{l}\text { up to } 50 \% \\
\text { (Team Teaching } \\
\text { Possible) }\end{array}$ & up to $15 \%$ & As Required \\
\hline Testing & Voluntary & Voluntary & Voluntary & Yes & Yes \\
\hline $\begin{array}{l}\text { Commuting } \\
\text { Expenses }\end{array}$ & Yes & Yes & No & Yes & Yes \\
\hline Child Care & Yes & No & Yes & No & No \\
\hline $\begin{array}{l}\text { Standardized } \\
\text { Teaching Material }\end{array}$ & No & No & No & No & No \\
\hline $\begin{array}{l}\text { Providers of } \\
\text { Language Courses }\end{array}$ & 788 & 348 & 445 & 9 & 4 \\
\hline $\begin{array}{l}\text { Planned Budget } \\
2000\end{array}$ & DM 240 million & DM 45 million & DM 34 million & DM 11 million & DM 0.65 million \\
\hline $\begin{array}{l}\text { Government } \\
\text { Department }\end{array}$ & $\begin{array}{l}\text { Federal } \\
\text { Ministry of } \\
\text { Labour and } \\
\text { Social Affairs } \\
(B M A)\end{array}$ & $\begin{array}{l}\text { Federal Ministry } \\
\text { for Family } \\
\text { Affairs, Senior } \\
\text { Citizens, Women } \\
\text { and Youth } \\
(B M F S F J)\end{array}$ & $\begin{array}{l}\text { Federal Ministry } \\
\text { of Labour and } \\
\text { Social Affairs } \\
(B M A)\end{array}$ & $\begin{array}{l}\text { Federal Ministry for } \\
\text { Family Affairs, } \\
\text { Senior Citizens, } \\
\text { Women and Youth } \\
(B M F S F J)\end{array}$ & $\begin{array}{l}\text { Federal Ministry } \\
\text { of Education and } \\
\text { Research }(B M B F)\end{array}$ \\
\hline
\end{tabular}




\begin{tabular}{|l|l|l|l|l|l|}
\hline $\begin{array}{l}\text { Realization/ } \\
\text { Conduction }\end{array}$ & $\begin{array}{l}\text { Federal Labor } \\
\text { Office } \\
\text { (Bundesanstalt } \\
\text { für Arbeit) }\end{array}$ & Federal States & Sprachverband & $\begin{array}{l}\text { Otto Benecke } \\
\text { Foundation }\end{array}$ & $\begin{array}{l}\text { Otto Benecke } \\
\text { Foundation }\end{array}$ \\
\hline Support & $\begin{array}{l}\text { Individual } \\
\text { Allowances, } \\
\text { Final Payment } \\
\text { to Provider, } \\
\text { Teaching Funds }\end{array}$ & $\begin{array}{l}\text { Individual } \\
\text { Allowances, } \\
\text { Subsidies for } \\
\text { Provider }\end{array}$ & $\begin{array}{l}\text { Contract and } \\
\text { Final Payment to } \\
\text { Provider }\end{array}$ & $\begin{array}{l}\text { Individual } \\
\text { Allowances, } \\
\text { Subsidies for } \\
\text { Provider }\end{array}$ & $\begin{array}{l}\text { Individual } \\
\text { Allowances, Final } \\
\text { Payment to } \\
\text { Provider }\end{array}$ \\
\hline Costs & $\begin{array}{l}\text { Average: } \\
\text { DM 722 per } \\
\text { Participant/ } \\
\text { Month }\end{array}$ & $\begin{array}{l}\text { DM 630/800/820 } \\
\text { per Participant/ } \\
\text { Month }\end{array}$ & $\begin{array}{l}\text { DM 35 } \\
\text { per Course Unit }\end{array}$ & $\begin{array}{l}\text { Average: } \\
\text { DM 900 per }\end{array}$ & $\begin{array}{l}\text { Average: } \\
\text { DM 750 per } \\
\text { Participant/Month }\end{array}$ \\
\hline
\end{tabular}

Source: Stellungnahme der Bundesregierung zu den Studien zur Sprachförderung, BMFSFJ/BMA Oct. 12, 2000; unofficial Translation 


\section{Appendix E}

Excerpts from Bill C-11 (Canada's Immigration and Refugee Protection Act)

\section{Proposed Points Grid}

$\underline{\text { Age }}$ 10pts MAX

21-44 $10 \mathrm{pts}$

lose 2 points for each year over 44

Education 25pts MAX

Doctorate or Masters $25 \mathrm{pts}$

BA 20pts

High School $5 \mathrm{pts}$

Language 20pts MAX

Highly functional in first official language $16 \mathrm{pts}$

Moderately functional in first official language 8 pts

Basic skills in first official language $0 \mathrm{pts}$

Highly functional in second language 4 pts

Source: Citizenship and Immigration Canada, Bill C-11: Immigration and Protection Act; www.cic.gc.ca/english/about/policy/c-11-regs.html - Nov. 2001 


\section{IZA Discussion Papers}

No. Author(s)

540

G. S. Epstein

A. Kunze

M. E. Ward

541

B. Cockx

M. Dejemeppe

542

M. Frölich

543

544

545

546
A. M. Stiglbauer
F. Stahl
R. Winter-Ebmer
J. Zweimüller

G. S. Epstein

I. N. Gang

548

M. Frölich

549

E. Wasmer

D. Clark

$$
\text { R. Fahr }
$$$$
\text { U. Sunde }
$$

$$
\text { S. Machin }
$$$$
\text { P. A. Puhani }
$$

W. Koeniger
D. J. DeVoretz
H. Hinte
C. Werner

Title

Area

Date

High Skilled Migration and the Exertion of Effort 1

$08 / 02$ by the Local Population

Do the Higher Educated Unemployed Crowd Out 2 the Lower Educated Ones in a Competition for Jobs

Programme Evaluation with Multiple Treatments

Wages, Productivity, and Work Intensity in the

Disentangling the Minimum Wage Puzzle: An

Analysis of Worker Accessions and Separations

The Role of Background Factors for Reading Literacy: Straight National Scores in the PISA 2000 Study

Job Creation and Job Destruction in a Regulated 2

08/02 Labor Market: The Case of Austria

Government and Cities: Contests and the Decentralization of Decision Making

What is the Value of Knowing the Propensity

Score for Estimating Average Treatment Effects?

Interpreting Europe and US Labor Markets Differences: The Specificity of Human Capital Investments

The Impact of Local Labour Market Conditions on Participation in Further Education in England

Herd Effects or Migration Networks?

The Location Choice of Mexican Immigrants in the U.S.

Estimations of Occupational and Regional

Matching Efficiencies Using Stochastic

Production Frontier Models

Subject of Degree and the Gender Wage

Differential Evidence from the UK and Germany 